\title{
PROCESSO E CONSTITUIÇÃO: AS POSSÍVEIS RELAÇÕES ENTRE O PROCESSO CIVIL E O DIREITO CONSTITUCIONAL NO MARCO TEÓRICO DO FORMALISMO-VALORATIVO
}

por Daniel Francisco Mitidiero

Introdução; 1. Possíveis Relações entre Processo e Constituição; 2. O Processo Civil no Marco Teórico do FormalismoValorativo; Conclusões; Referências Bibliográficas.

\section{Introdução}

O presente estudo visa a explorar as possíveis relações entre o processo civil e o direito constitucional no marco teórico do formalismo-valorativo. Num primeiro momento, expõem-se as recíprocas influências entre o processo e a Constituição, para logo em seguida analisar-se o direito processual civil em seu momento atual, o formalismo-valorativo, e o âmbito de abrangência do processo constitucional no direito brasileiro.

\section{Possíveis Relações entre o Processo Civil e a Constituição}

As relações entre o processo civil e a Constituição são relações dialógicas, de recíproca implicação. Há na doutrina contemporânea um diálogo constante entre o direito processual civil e o direito constitucional, a ponto de muitos autores falarem, de um lado, em uma teoria processual da Constituição ${ }^{\dagger}$ e, de outro, surpreendendo o tema por um ângulo diverso de visão, em uma teoria constitucional do processo, como desdobramento da força normativa da Constituição especificamente canalizada para o campo

Assim, entre outros, fosé Jodquim Gomes Canotilho, Direito Constitucional e Teoria da Constituição, 3. ed. Coimbra: Almedina, 1999, pp. 1292/1295; na doutrina brasileira, Willis Santiago Guerra Filho, Teoria Processual da Constituição, 2. ed.. São Paufo: Celso Bastos Editor, 2000, principalmente pp. $21 / 25$. 
de atuação do processo civil². No fundo, uma processualização da Constituição, a par de uma concomitante constitucionalização do processo ("materialização do direito processual"3).

\section{As duas abordagens nos interessam.}

Consoante observa José Joaquim Gomes Canotilho, uma das tendências sugeridas pelo discurso constitucional contemporâneo é a processualização da Constituição, que responderia às exigências de uma moral racional flexível ou mora racional comunicativa. "Concordantemente com a relativização dos "critérios absolutos de verdade" ", escreve Canotilho, "a processualizaçāo visa não tanto garantir posições jurídicas subjectivas ou prestações sociais mas sim assegurar ou estabelecer condiçōes de possibilidade dessas prestações e dessas garantias. A processualização da constituição radicaria, portanto, na

Sobre a força normativa da Constituiçāo, consulte-se o clássico Konfad Hesse, A Força Normativa da Constituição. Porto Alegre: Sérgio Antônio Fabris Editor, 1991. Para uma aplicaçăo dessa idéia ao processo civil, consulte-se, entre outros, na doutrina brasileira, Carlos Alberto Alvaro de Oliveiła, Do Formalismo no Processo Civíl, 2, ed.. Săo Paulo: Saraiva, 2003, pp. 83/108; "A Garantía do Contraditório". In: Do Formalismo no Processo Civil, 2. ed. Sào Paulo: Saraiva, 2003, pp. 227/243; "O Processo Civil na Perspectiva dos Direitos Fundamentais". In: Alvaro de Oliveira, Carlos Alberto (org.), Processo e Constituição. Rio de Janeiro: Forense, 2004, pp. 1/15; Luiz Guitherme Marinoni, Técnica Processual e Tutela dos Direitos. São Paulo: Revista dos Tribunais, 2004, pp. 165/247; Novas linhas do Processo Civil, 4. ed. São Paulo: Malheiros, 2000, pp. 181/265; Candido Rangel Dinamarco, Instituiçoes de Direito Processual Civil, 3. ed.. Săo Paulo: Maltheiros, 2003, pp. 188/253, vol. l; Nélson Nery Jủnior, Princípios do Processo Civil na Constituição Federal, 5. ed.. Säo Paulo: Revista dos Tribunais, 1999; Ada Pellegrini Grinover, As Garantias Constitucionais do Direito de Ação. São Paulo: Revista dos Tribunais, 1973; Os Princípios Constitucionais e o Código de Processo Civil. Săo Paulo: josé Bushatsky Editor, 1975; Hermes Zaneti Júnior, "Processo Constitucional: Relações entre Processo e Constifuiçäo". In: Introdução ao Estudo do Processo Civil ... Primeiras Linhas de um Paradigma Emergente. Porto Alegre: Sérgio Antonio Fabris Editor, 2004, pp. 23/62, em co-autoria com Daniel Francisco Mitidiero; Daisson Flach, "Processo e Realização Constitucional: a Construçăo do 'Devido Processo'". In: Amaral, Guilherme Rizzo e Carpena, Márcio Louzada (coords.), Visões Críticas do Processo Civil Brasileiro - Uma Homenagem ao Prof. Dr. José Maria Rosa Tesheiner. Porto Alegre: Livraria do Advogado, 2005, pp. 11/30; Sergio Luis Wetzel de Mattos, "O Processo Justo na Constituiçăo Federal de 1988". In: Revista da Ajuris. Porto Alegre: s/ed., 2003, pp. 215/260, n. 91; Maristela da Silva Alves, "Processo e Constituição". In: Revista da Ajuris. Porto Alegre: s/ed,, 2002, pp. 256/272, n. 85, tomo 1; na doutrina italiana, Envico Tullio Liebman, "Diritto Costituzionale e Processo Civile". In: Problemi del Processo Civile. Napoli: Morano Editore, 1962, pp. 149/154; Nicolò Trocker, Processo Civile e Costituzione - Problemi di Diritto Tedesco e Italiano. Milano: Giuffrè, 1974; "Il Nuovo articolo 117 della Costituzione e il "Giusto Processo' in Materia Civile: Profliti Generali". In: Rivista Trimestrale di Diritto e Procedura Civile. Milano: Giuffrè, 2001, pp. 381/410, n. 2; Luigi Paolo Comoglio, La Garanzia Costituzionale dell'Azione ed il Processo Civile. Padova: Cedam, 1970; "I Modelli di Garanzia Costituzionale del Processo". In: Rivista Trimestrale di Diritto e Procedura Civile. Milano: Giluffrè, 1991, pp. 673/741, anno XIV; Sergio Chiartoni, "1l Nuovo art. 111 Cost. e il Processo Civile". In: Rivista di Diritto Processuale. Padova: Cedam, 2000, anno LV, pp. 1.010/1.034, n. 4; Andrea Proto Pisani, "Giusto Processo e Valore della Cognizione Piena". In: Rivista di Diritto Civile. Padova: Cedam, 2002, pp. 265/280, n. 2; na doutrina argentina, Augusto M. Morello, Constitución y Proceso - La Nueva Edad de las Garantías Jurisdiccionales. La Plata: Libreria Editora Plátense, 1998; na doutrina uruguaia, Eduardo Juan Couture, "Las Garantías Constitucionales del Proceso Civil". In: Estudios de Derecho Procesal Civil. Buenos Aires: Ediar Editores, 1948, tomo I; na doutrina peruana, Juan Monroy Gálvez, Introducción al Proceso Civil. Bogotá: Temis, 1996, p. 271, tomo I.

3 Assim, Willis Santiago Guerra Fitho, Teoria Processual da Constituiçăo, 2. ed.. São Paulo: Celso Bastos Editor, 2002, p. 27. 
transformação do contexto social de liberdade geral num sistema de justificação do novo contexto social de idéias e interesses"4. Tal é "a processualidade heraclitiana da Constituição", na verba de Carlos Ayres Britto ${ }^{5}$. Não se quer com isso, porém, esvaziar a materialidade inerente ao direito constitucional. De modo nenhum. Como reconhece o próprio constitucionalista lusitano, "a reflexividade pós-moderna não elimina a compreensão racional da modernidade constitucional. A consciência projectante dos homens e a força conformadora do direito permanecem como background filosófico-político do constitucionalismo moderno. A constituição de um estado de direito democrático terá de continuar a propor uma melhor organização da relação homem-mundo e das relações intersubjectivas (entre e com os homens) segundo um projectoquadro de 'estruturas básicas da justiça'" ${ }^{\prime}$. Novamente com Carlos Ayres Britto ${ }^{7}$ : a processualidade heraclitiana da Constituição não apaga a sua "antiprocessualidade parmediana", já que toda Constituição concilia dinâmica e estabilidade, processo e substância.

De outro lado, a conexão cada vez mais explorada entre o processo civil e a Constituição, acentuada após o segundo pós-guerra com a constitucionalização e a fundamentalização de variegadas garantias processuais, impele a uma teoria constitucional do processo, seja no que toca à vivificação da análise da matriz constitucional do processo civil, seja no que concerne à nova leitura dos institutos processuais fundamentais ${ }^{8}$. Com efeito, a doutrina contemporânea está a cuidar para que se preencham adequadamente os espaços deixados pelo abstracionismo de cariz pandectístico que dominou a "ciência" processual da primeira metade do breve século XX, substancializando o processo com as normas constitucionais. O processo de maneira alguma pode ser identificado com a pura forma, sendo de todo inadequado não atentar ao conteúdo do direito processual civil contemporâneo. Aliás, formalismo não é sinônimo de forma, como já demonstrou outrora magistralmente Carlos Alberto Alvaro de Oliveira9?.

Partindo-se de uma postura constitucional de processo, própria do formalismo-valorativo (adiante, n. 2), mostra-se fundamental a análise do devido processo legal processual brasileiro, porque nele se encontra a disciplina mínima de nosso formalismo, emanada diretamente de nossa Constituição, o nosso

\footnotetext{
Direito Constitucional e Teoria da Constituiçăo, 3. ed. Coimbra: Almedina, 1999, p. 1294.

Teoria da Constituição. Rio de Janeiro: Forense, 2003, p. 210.

Direito Constitucional e Teoria da Constituição, 3. ed.. Coimbra: Almedina, 1999, p. 1295.

Teoria da Constituição. Rio de Janeiro: Forense, 2003, p. 214.

Releitura que buscamos empreender, por exemplo, nos conceitos de jurisdiçäo, "açăo" e processo fconforme Daniel Francisco Mitidiero, Elementos para uma Teoria Contemporânea do Processo Civil Brasileiro. Porto Alegre: Livraria do Advogado, 2005, pp. 75/145) e, também, no grave e tormentoso problema das invalidades no direito processual civil (conforme Daniel Francisco Mitidiero, Comentários ao Código de Processo Civil. São Paulo: Memória Jurídica Editora, 2005, pp. 382/425, tomo \#l).

9 Do Formalismo no Processo Civil, 2, ed.. São Paulo: Saraiva, 2003, pp. 6/9.
} 
modelo constitucional de processo civil, como observam Cândido Rangel Dinamarco ${ }^{10}$ e joão Batista Lopes ${ }^{11}$. Cuidando o processo civil, no fundo, da "domesticação do arbítrio estatal dentro do processo"12, natural que a cláusula do procedural due process of law, erigida entre nós à categoria de direito fundamental, formal e materialmente ${ }^{13}$, galgue posição de destaque. $O$ devido processo legal processual brasileiro é o nosso modelo mínimo de processo équo: da sua fiel consecução, pois, depende mesmo a própria obtenção da justiça através do processo, uma vez que somente de um processo justo podem advir decisōes justas, como bem observa, entre outros, Marie-Emma Boursier ${ }^{i 4}$.

Em seu aspecto objetivo, o direito fundamental à jurisdição prestada de acordo com o devido processo legal processual revela a posição que esse ocupa em nossa escala de valores constitucionais, o que é altamente llustrativo da dignidade emprestada à categoria pelo constituinte. Em seu aspecto subjetivo, faz justiciável, sindicável o próprio direito ao devido processo legal processual ${ }^{15}$. Aliás, é mesmo por definição, como lembra Jorge Miranda ${ }^{16}$, que os direitos fundamentais têm de receber proteção judiciária, essa mesma, de resto, passível de atuação judiciária.

Segundo Carlos Alberto Alvaro de Oliveira, a construçāo de um processo justo, do devido processo legal processual brasileiro, é uma empresa que só se pode ultimar tendo em conta as peculiaridades dos mais diversos casos concretos levados à apreciação do Poder Judiciário, tendo em conta o caráter principiológico assumido pelos direitos fundamentais no constitucionalismo contemporâneo ${ }^{17}$. Vale dizer: a construção de um "processo justo e équo"18, embora conte com bases constitucionais mínimas, com um "conteúdo mínimo essencial"19, com um "núcleo forte ineliminável", na expressão de Andrea Proto

${ }_{30}$ Instituiçōes de Direito Processual Civil, 3. ed. São Paulo: Malheiros, 2003, p. 180, vol. I.

i) Curso de Direito Processual Civil. Sảo Paulo: Atlas, 2005, p. 38, vol. 1.

\2 Carlos Alberto Alvaro de Oliveira, Do Formalismo no Processo Civil, 2, ed. São Paulo: Saraiva, 2003, p. 83.

13 Sobre o assunto, Ingo Wolfgang Sarlet, A Eficácia dos Direitos Fundamentais, 4. ed.. Porto Alegre: Livraria do Advogado, 2004, pp. $86 / 90$.

is Le Principe de Loyauté en Droit Processuel. Paris: Dalloz, 2003, p. 425.

15 Acerca da perspectiva objetiva e da perspectiva subjetiva dos direitos fundamentais, consulte-se, entre outros, José Carlos Vieira de Andrade, Os Direitos Fundamentais na Constituição Portuguesa de $1976,2$. ed. Coimbra: Almedina, 2001, pp. 109/155.

16 Manual de Direito Constitucional, 3. ed.. Coimbra: Coimbra Editora, 2000, p. 257, tomo IV.

3 "O Processo Civil na Perspectiva dos Direitos Fundamentais". In: Alvaro de Oliveira, Carlos Alberto (org.), Processo e Constituição. Rio de Janeiro: Forense, 2004, p. 15.

18 A expressão é de Cândido Rangel Dinamarco, Instituiçōes de Direito Processual Civil, 3. ed.. São Paulo: Malheiros, 2003, p. 247, vol. I.

19 Luigi Paolo Comoglio, la Garanzia Costituzionale dell'Axione ed il Processo Civile. Padova: Cedam, 1970 , p. 156. Entre outros elementos, lembra Comoglio a necessidade de observância do juiz natural, da independência e da imparcialidade do ógăo jurisdicional, da igualdade entre as partes e do contraditório. Acerca, consulte-se, com grande proveito, Carlos Alberto Alvaro de Oliveira, Do Formalismo no Processo Civil, 2, ed.. Sắ Paulo: Saraiva, 2003, pp. $85 / 87$ 
Pisani ${ }^{20}$, só pode ser atualizada e finalizada em concreto, haja vista a problematicidade inerente ao fenômeno jurídico ${ }^{21}$. Não há, pois, um devido processo legal processual desenhado cabalmente em abstrato, como observa Giovanni Verde ${ }^{22}$, decorrendo mesmo essa insuficiência das previsōes legislativas da natureza do direito, arredio a apreensōes apriorísticas, sempre reducionistas da complexidade das coisas, já que situado no domínio históricocultural, como apanha Antônio Menezes Cordeiro ${ }^{23}$. Nada obstante, parecenos fecunda a pormenorização das bases mínimas de nosso formalismo processual, empresa que se levará a cabo em tópico próprio, ainda que se trate de empresa precária e sujeita à atualização concreta (o devido processo legal é sempre um conceito em construção, como bem destaca Daisson Flach ${ }^{24}$ ), concorrendo, no mínimo, para densificação do sentimento constitucional dentro da esfera do processo civil ${ }^{25}$.

De um lado, processualização da Constituição; de outro, constitucionalização do processo. Sobre esses influxos, a doutrina costuma apontar ainda uma confluência temática entre direito constitucional e direito processual civil ou, ainda mais precisamente, entre direitos fundamentais e devido processo legal processual. Ainda com Canotilho, "existe uma relação recíproca de efeitos ou uma interdependência relacional entre direitos fundamentais (direito material) e procedimento (direito procedimental e processual)", motivo pelo qual "a organizaçāo e o procedimento, nas suas repercussōes sobre o direito material, devem ser perspectivadas à luz dos direitos fundamentais" e "o direito material, na sua irradiação sobre a organização do procedimento, não deve dissociar-se da importância do due process para a garantia ou proteção jurídica dos direitos fundamentais" 26 .

20 "Giusto Processo e Valore della Cognizione Piena". In: Rivista di Diritto Civile. Padova: Cedam, 2002, p. 267, n. 2.

21 Assim, por todos, Antônio Castanheira Neves, Metodologia Juridica - Problemas Fundamentais. Coimbra: Coimbra Editora, 1993, pp. 33/34.

22 Com efeito, ressalta Giovanni Verde que "il giusto processo, insomma, non appartiene alla 'natura dele cose'; è il precipitato di valori mutevoli ed è collegato a diverse ed egualmente possibili soluzioni tecniche, trá cui bisogna operare scelte secondo una scala di priorită" ("Ciustizia e Garanzie nella Giurisdizione Civile". In: Rivista di Diritto Processuale. Padova: Cedam, 2000, p. 308, n. 2).

23 Introdução à Edição Portuguesa de Pensamento Sistemático e Conceito de Sistema na Ciência do Direito de Claus-Wilhelm Canaris, 3. ed. Lisboa: Calouste Gulbenkian, 2002, p. XX.

24 "Processo e Realização Constitucional: a Construção do 'Devido Processo" . In: Amaral, Guilherme Rizzo e Carpena, Mărcio Louzada (coords.), Visöes Críticas do Processo Civil Brasileiro - Úma Homenagem ao Prof. Dr. José Maria Rosa Tesheiner. Porto Alegre: Livraria do Advogado, 2005, pp. 11/30.

25 Sobre o sentimento constitucional, consulte-se Pablo Lucas Verdú, Sentimento Constitucional - Aproximação ao Estudo do Sentir Constitucional como Modo de Integração Política. Rio de Janeiro: Forense, 2004.

26 "Tópicos de um Curso de Mestrado sobre Direitos Fundamentais, Procedimento, Processo e Organizaçăo". In: Boletim da Faculdade de Direito de Coimbra. Coimbra, 1990, p. 157. 
A confluência está, justamente, na interdependência eficacial entre os dois termos da equação que, no fundo, é a mesma que se estabelece entre direito material e processo, consoante já observamos alhures ${ }^{27}$, mas já aí em outro nível de densidade normativa, porque tratada exclusivamente em sede de direito constitucional. Também esse diálogo recomenda que se pormenorize as bases de nosso processo justo, programa mínimo dessa profícua relação.

\section{O Processo Civil no Marco Teórico do Formalismo-Valorativo}

O direito processual civil no marco teórico do formalismo-valorativo nāo pode ser outro que o projetado constitucionalmente, sendo um processo que se configura como um direito fundamentai, com as dimensōes e a eficácia peculiares a essa categoria político-jurídica. Passada a pré-história do processo civil, na qual esse vinha identificado com a mera praxe, normalmente tratado dentro de exposições gerais de direito material privado, como observa Riccardo Orestano ${ }^{28}$, firme testemunho de seu caráter acessório, e abandonada a vazia autonomia que a "ciência" processual the impôs, cuja abstração e assepsia levou-o ao encastelamento, relegado à mera técnica, o formalismo-valorativo compreende o processo civil como um elemento da cultura de corte constitucional, com o desiderato de realizar a justiça do caso levado à apreciação do Poder Judiciário ${ }^{29}$.

Nessa vertente, nosso modelo constitucional de processo civil exige inafastabilidade da jurisdição (abstração da "ação" processual), juiz natural (imparcial e competente), processo público e com duração razoável, levado a efeito em condições de paridade, observando-se o contraditório e a ampla defesa e, bem assim, as motivações das decisōes judiciais, combinando-se

27 Conforme Elementos para uma Teoria Contemporànea do Processo Civil Brasileiro. Porto Alegre: Livraria do Advogado, 2005, pp. 66/73.

28 "Azione, 1 - L'Azione in Generale: a) Storia del Problent". In: Enciclopedia del Diritto. Milano: Giuffrè, 1959, p. 790, vol. IV.

29 Para uma całacterizaçăo um pouco mais detalhada do formalismo-valorativo, consulte-se Daniel Francisco Mitidiero, Elementos para uma Teoria Contemporânea do Processo Civil Brasileiro. Porto Alegre: Livraria do Advogado, 2005, pp. 19/21. Esclareça-se, de resto, que o termo "formalismo-valorativo" fora cunhado por Carlos Alberto Alvaro de Oliveira, no ano de 2004, en seminários realizados no ámbito do programa de pós-graduação en direito (mestrado e doutorado) da Universidade Federal do Rio Grande do Sul. 
elementos típicos da família continental com características indissociáveis da tradição anglo-saxônica ${ }^{30}$, oferecendo aquele "termo intercalar" entre o "judicial control" e a concepção européia, a que aludia de há muito Pontes de Miranda ${ }^{31}$, no rastro de uma conformação ótima dos fundamentos do direito constitucional brasileiro. Convém detalhálo, ainda que em golpes de pincel.

Refere a nossa Constituição que "ninguém será privado da liberdade ou de seus bens sem o devido processo legal" (art. 50, LIV) ${ }^{32}$. Trata-se de norma que, concomitantemente, principia e enfeixa a disciplina do processo civil brasileiro (a rigor, principia e enfeixa a disciplina do processo jurisdicional brasileiro, seja civil, penal ou trabalhista). Principia, porque dela poderíamos extrair todas as demais, nas abalizadas opiniōes de Carlos Alberto Alvaro de Oliveira ${ }^{33}$ e Nélson Nery Júnior ${ }^{34}$; enfeixa, porquanto propicia abertura a outras normas que eventualmente se façam necessárias para compor, em concreto, o devido processo legal processual brasileiro ${ }^{35}$.

Embora a doutrina tenha dificuldades em demarcar precisamente o que compõe e o que não compõe o devido processo legal processual, tendo em conta mesmo a sua indefinibilidade apriorística ${ }^{36}$, certo é que esse tem um conteúdo mínimo sem o qual, evidentemente, se está a frustrar essa norma constitucional. Assim, ensina Nicolò Trocker, em atenção ao direito

30 Anote-se que as expressỏes "família" e "tradiçaco" estăo sendo utlizadas com o mesmo significado nesse ensaio, querendo expressar um conjunto de atitudes profundamente arraigadas, historicamente condicionadas, acerca da natureza do direito, acerca do papel do direito na sociedade, acerca da organização e da operaçăo adequadas de um dado sistema jurídico e acerca da forma com que se faz, que se aplica, que se estuda e ensina-se o direito (conforme John Henry Merryman, La Tradición Jurídica Romano-Canónica, 5. reimpressão. México: Fondo de Cultura Económica, 2000, p. 17). Allás, o termo "sistema", utilizado, por exemplo, na obra de John Gilissen, Introdução Histórica ao Direito, 4. ed.. Lisboa: Fundaçăo Calouste Gulbenkian, 2003 , p. 19, näo retrata bem o fenômeno ora trabalhado, porque sugere a existência de uma ordem e de uma unidade (caracteristicas do conceito geral de sistema, conforme Claus-Wilhelm Canaris, Pensamento Sistemático e Conceito de Sistema na Ciência do Direito, 3. ed.. Lisboa: Fundaçäo Calouste Gubenkian, 2002, p. 12) entre os diversos direitos nacionais que eventualmente compoem uma familia ou ensartam-se na mesmá tradiçăo, o que, no mais das vezes, nảo se verifica.

3 Os Fundamentos Actuaes do Direito Constitucional. Rio de Janeiro: Freitas Bastos, 1932, p. 116.

32 Para um histórico da cláusula, consulte-se, na doutrina brasileira, Ada Pellegrini Grinover, As Garantias Constitucionais do Direito de Ação. Sảo Paulo: Revista dos Tribunais, 1973, pp. 23/38; na douttina italiana, referindo-se especificamente ao ambiente constitucional europeu, Nicolò Trocker, "Il Nuovo articolo 111 della Costituzione e il 'Giusto Processo' in Materia Civile: Profilis Generali". In: Rivista Trimestrale di Diritto e Procedura Civile. Milano: Gíffrè, 2001, pp. 383/386, n. 2.

33 Do Formalismo no Processo Civil, 2. ed.. São Paulo: Saraiva, 2003, p. 85.

${ }_{34}$ Princípios do Processo Civil na Constituiçäo Federal, 5. ed.. São Paulo: Revista dos Tribunais, 1999, p. 30.

35 Cândido Rangel Dinamarco, Instituições de Direito Processual Civil, 3. ed.. São Paulo: Malheiros, 2003, p. 245, vol. 1 .

36 Assim, por tocios, Carlos Alberto Alvaro de Oliveira, "O Processo Civil na Perspectiva dos Direitos Fundamentais". In: Alvaro de Oliveira, Carlos Alberto (org.), Processo e Constituição. Rio de faneiro: Forense, 2004, pp. 1/15. 
constitucional italiano (precisamente, art. 11137), que "giusto è il processo che si svolge nel rispetto dei parametri fissati dalle norme costituzionali e dei valori condivisi dalla collettività. E tale è il processo che si svolge davanti ad un giudice imparziale nel contraddittorio di tutti gli interessati in un tempo ragionevole ${ }^{\prime \prime 38}$. Com relação ao direito brasileiro, observa Carlos Alberto Alvaro de Oliveira que "para além das garantias correspondentes ao órgão judicial e do caráter fundamental da garantia de acesso à jurisdição, do ponto de vista estritamente processual, o conceito de devido processo legal compreende a estruturação correta do procedimento, permitindo tendencialmente aos litigantes as garantias da publicidade, contato direto do juiz com as partes e tramitação rápida do expediente. Todavia, como o processo não se resume a uma simples seqüência ordenada de atos, o princípio não se esgota em assegurar a regularidade do procedimento, abrangendo também a possibilidade de ambas as partes sustentarem suas razões e apresentarem suas provas e, assim, influírem por meio do contraditório na formaçāo do convencimento do juiz. Por tais razões, o aspecto mais essencial do devido processo legal é o de assegurar o contraditório e a ampla defesa. No fundo, a garantia do devido processo legal constitui a expressão constitucional do formalismo processual; o informalismo excessivo (em que as partes perigam sossobrar ao arbítrio e ao poder do Estado) e o excesso de formalismo (em que o conteúdo - o direito material e a justiça - corre o risco de periclitar por razóes de forma) estabelecem os seus limites externos. Aspecto importante, substrato mesmo do princípio em análise, concerne à igualdade. É preciso atentar, porém, para que a igualdade entre as partes não seja apenas formal mas também material, real. Para esse efeito, a expressão e o próprio conceito á implicado de igualdade de armas (Waffeng/eichheit) mostram-se altamente significativos ${ }^{\prime 39}$. Vale dizer: a fórmula mínima do devido processo legal processual brasileiro, como já observado, está em garantir-se a inafastabilidade da jurisdição, o juiz natural, a paridade de armas, o contraditório, a ampla defesa, a publicidade, a motivação da sentença e a duração razoável do processo ${ }^{40}$. Fora daí, fere-se nosso perfil constitucional de processo, desprestigiando-se, pois, a dimensão objetiva dos

3 Reza o art. 111, primeira, segunda e terceira partes da Constituiçäo italiana: "La giurisdizione si atuua mediante il giusto processo regolato dalla legge. Ogai processo si svolge nel contraddittorio tra le parti, in condizioni di parità, davanti a gìdice terzo e imparziale. La legge ne assicura la ragionevole durata".

36 "Il Nuovo articolo 111 della Costituzione e il 'Giusto Processo' in Materia Civile: Profili Generali". In: Rivista Trimestrale di Diritto e Procedura Civile. Milano: Giuffiè, 2001, p. 386, n. 2.

39 Do Formalismo no Processo Civil, 2. ed.. Sāo Paulo: Saraiva, 2003, pp. 85/86.

to Ao lado da acepção processual da cláusula do devido processo legal, a doutrina costuma aludir também à existência do substantive due process of law, que, ao fim e ao cabo, funcionaria como uma proibição à produçäo de atos normativos näo-razoáveis (sobre esse assunto, consulte-se, por todos, Nélson Nery Júnior, Princípios do Processo Civil na Constituição Federal, 5. ed.. Sâo Paulo: Revista dos Tribunais, 1999, pp. 35/38). 
direitos fundamentais encartados em nosso formalismo processual, como observa Joan Picó i Junoy ${ }^{41}$.

O processo civil, em si considerado, é um direito fundamental ${ }^{42}$, cuja essencialidade fora ainda mais acentuada em face da "vocação do nosso tempo para a jurisdição", bem diagnosticada por Nicola Picardi ${ }^{43}$. Trata-se mesmo de um "direito charneira", como bem apontado por Boaventura de Sousa Santos, na medida em que a sua própria realização é uma condição de efetivação dos demais direitos fundamentais, na medida em que a sua "denegação acarretaria a de todos os demais" 44 . Iniciamse o processo com o exercício da "ação" processual, apresentando-se ao Poder Judiciário dada situação jurídica para que esse a resolva, fazendo justiça. $O$ direito ao processo, pois, concretiza-se, sob o ponto de vista do demandante, outorgando-se ao mesmo o direito e a pretensão à tutela jurídica, franqueando-se a esse a "ação" processual como um veículo eficaz de acesso ao processo. Do ponto de vista do Estado, garantese o direito ao processo através da inafastabilidade da jurisdição, devendo o órgāo jurisdicional prestar tutela jurisdicional adequada, tempestiva e efetiva a quantos dela necessitem, promovendo-se, dessarte, o acesso à ordem jurídica justa, ao processo justo e équo. É como refere Robert Alexy: o direito fundamental ao processo jurisdicional é um direito a uma "proteção jurídica efetiva" ou simplesmente não é, não se legitima no quadro teórico dos direitos fundamentais ${ }^{45}$.

A Constituição da República garante a abstração da "ação" processual e a inafastabilidade da jurisdiçāo, como já comentamos noutro lugar ${ }^{46}$, em seu

41 "El Sistema Español de Garantlas Constitucionales del Proceso". In: Revista Peruana de Derecho Procesal. Lima: Estudio Monroy Abogados, 1999, p. 270, vol. Ill. A observaçăo, embora referente especificamente ao processo civil espanhol, tem cabida entre nós, em face da similitude das nomas jurf́dicas envolvidas. Quanto à dimensäo objetiva dos direitos fundamentais, consulte-se, na doutrina brasileira, por todos, Ingo Wolfgang Sarlet, A Eficácia dos Direitos Fundamentais, 4. ed.. Porto Alegre: Livraria do Advogado, 2004, pp. 151/161; na portuguesa, por todos, José Carlos Vieira de Andrade, Os Direitos Fundamentais na Constituição Portuguesa de 1976, 2. ed.. Coimbra: Almedina, 2001, pp. 138/155.

42 Assim, na doutrina brasileira, Canlos Alberto Alvaro de Oliveira, "O Processo Civil na Perspectiva dos Direitos Fundamentais". In: Alvaro de Oliveira, Carlos Alberto (org.), Processo e Constituição. Rio de Janeiro: Forense, 2004, pp. 1/15; Luiz Guilherme Marinoni, Técnica Processual e Tutela dos Direitos. São Pauto: Revista dos Tribunais, 2004, pp. 165/247; Cândido Rangel Dinamarco, Instituições de Direito Processual Civil, 3. ed.. São Paulo: Malheiros, 2003, p. 247, vol. I; na doutrina peruana, Juan José Monłoy Palacios, Bases para la Formulación de una Teoría Cautelar. Lima: Comunidad, 2002, pp. 70/71.

4.3 "La Vocazione del Nostro Tempo per la Giurisdizione". In: Rivista Trimestrale di Diritto e Procedura Civile. Milano: Giuffrè, 2004, pp. 41/71, n. 1.

44 Pela Mão de Alice - O Social e o Político na Pós-Modernidade, 9. ed.. São Paulo: Cortez Editora, 2003, p. 167; nesse mesmo sentido, Luiz Guilherme Marinoni, Técnica Processual e Tutela dos Direitos. São Paulo: Revista dos Tribunais, 2004, pp. 184/185.

45 Teoría de los Derechos Fundamentales. Madrid: Centro de Estudios Políticos y Constitucionales, 2001, p. 472.

46 Daniel Francisco Mitidiero, Comentários ao Código de Processo Civil. Săo Paulo: Memória Jurídica Editora, 2004, p. 59, tomo I. 
art. $5^{\circ}, X X X V$, em que se afirma que "a lei não excluirá da apreciação do Poder Judiciário lesão ou ameaça a direito" ${ }^{\prime 7}$. A propósito, a Lei Fundamental da Alemanha igualmente o faz em seu art. 19, $\mathrm{IV}^{48}$. Todos, pois, têm direito de acorrer ao Poder Judiciário, de provocar a jurisdição mediante o exercício da "ação" processual, instaurando-se, dessarte, o processo ${ }^{49}$.

Discorrendo sobre a inafastabilidade do Poder Judiciário, ensina Ricardo de Oliveira Paes Barreto que, por esse princípio, "nem a lei, nem a vontade das partes pode retirar da apreciação jurisdicional lesão ou ameaça a direito" 50 , mas temos que atender que, aí, está a se extrapolar o conteúdo dessa cláusula constitucional. Com efeito, mostra-se possível aos sujeitos de dada relação jurídica afastar a apreciação jurisdicional, preferindo-se a arbitragem como meio de solução de seus eventuais $\operatorname{conflitos}^{53}$. Certo, é evidente que esse afastamento não é absoluto, sobrando possível ao Poder Judiciário, em alguns casos específicos, como bem lembra Eduardo Silva da Silva ${ }^{52}$, controverter a atividade arbitral, mas aí já se está a laborar no terreno da exceção. Na generalidade dos casos é constitucionalmente possível optar pela solução arbitral, sem que se agrida, com isso, a cláusula da inafastabilidade da jurisdição.

47 Na realidade, como bem pondera Ovídio Araújo Baptista da Silva, "quando, porém, a Constituição, ou algum outro texto de direito público, afirma, querendo referi-se à garantia de acesso ao Poder fudiciário, que a lee assegura a todos o direito de serem ouvidos pelos tribunais, 'em caso de lesão ou ameaça de lesăo do direito', está a fazer afimaçăo incorfeta: o diteito de ser ouvido pelos tribunais é assegurado a todos indistintamente, tanto aos que tenham quanto aos que não tenham sofrido qualquer violaçăo ou ameaça a seus direitos; a até mesmo àqueles que, näo tendo direito algum, exijam que o Estado thes preste tutela jurisdicional, ainda que seja para que o juiz o declare sem direito" (Curso de Processo Civil, 5. ed.. São Paulo: Revista dos Tribunais, 2000 , p. 88 , vol. 1). De resto, sobre a garantia do acesso à jurisdiçâa no direito comparado e seu cotejo com o direito brasileiro, consulte-se Carlos Alberto Alvaro de Oliveira, Do Formalismo no Processo Civil, 2. ed.. São Paulo: Saraiva, 2003, pp. 89/103; sobre a norma da inatastabilidade do controle jurisdicional em geral, consulte-se Zaiden Geraige Neto, $\mathrm{O}$ Princípio da Inafastabilidade do Controle Jurisdicional - Art. 5o, XXXV, da Constituiçăo Federal. São Paulo: Revista dos Tribunais, 2003. Conforme a indicação de Ingo Wolfgang Sarlet, A Eficácia dos Direitos Fundamentais, 4. ed.. Porto Alegre: Livraria do Advogado, 2004, p. 82.

49 A única situação constitucional em que se afasta expressamente a jurisdiçăo é a contida no ast. $217, \$ 10$, que impõe o prévio recurso à justiça desportiva como condiçăo de acesso à jurisdiçăo. Problema que se imbrica com essa temática, mas que com ele nāo se confunde (uma vez que já pressupöe a existência do processo, da jurisdição e, portanto, do exercício da "ação"), reside nos limites da atividade jurisdicional. Sobre esse assunto, consulte-se, entre outros, José Maria Rosa Tesheiner, Elementos para uma Teoria Geral do Processo. São Paulo: Saraiva, 1993, pp. 31/35; Cláudio Ari Mello, Democracia Constitucional e Direitos Fundamentais. Porto Alegre: Livraria do Advogado, 2004, pp. 203/300.

Curso de Direito Processual Civil, 2. ed.. Rio de Janeiro: Renovar, 2003, p. 6.

5i A arbitragem, entre nós, vem disciplinada na Lei n. 9.307, de 1996. Sobre o assunto, entre outros, consultese Eduardo Silva da Silva, Arbítragem e Direito da Empresa - Dogmática e Implementação da Cláusula Compromissória. São Paulo: Revista dos Tribunais, 2003.

52 "Constituição, Jurisdição e Arbitragem". In: Alvaro de Oliveira, Carlos Alberto (org.), Processo e Constituição. Rio de Janeiro: Forense, 2004, p. 403. 
O Supremo Tribunal Federal, de resto, já se pronunciou inúmeras vezes nesse sentido $^{53}$. Eventual inconstitucionalidade reside na exclusão legal da apreciação do Poder Judiciário de qualquer alegação de lesão ou ameaça a direito e não na opção privada ao juízo arbitral, calcada na autonomia negocial, que ostenta igualmente estatura constitucional entre nós ${ }^{54}$.

Diante do regime constitucional passado (especificamente, art. 153, $\S$ $4^{\circ}$, segunda parte, com a redação outorgada pela $\mathrm{EC}$. 7 , de 1977), costumavase aludir à existência no ordenamento brasileiro, em alguns casos (notadamente em pleitos contra a Fazenda Pública), de uma espécie de jurisdição condicionada, na medida em que se autorizava à legislação infraconstitucional exigir o prévio esgotamento da via administrativa para que se pudesse recorrer à via jurisdicional. O direito constitucional vigente não repetiu essa odiosa ressalva. Como ensina Nélson Nery Júnior, "não mais se permite, no sistema constitucional brasileiro, a denominada jurisdição condicionada ou instância administrativa de curso forçado. Já se decidiu que não é de acolher-se a alegação da Fazenda Pública, em ação judicial, de que não foram esgotadas as vias administrativas para obter-se o provimento que se deseja em juízo" ${ }^{\prime \prime 5}$.

De outro lado, os processualistas adquiriram a consciência que não basta enunciar formalmente a cláusula da inafastabilidade da jurisdição, da abstração da "ação" processual: é necessário que a jurisdição seja da mesma forma socialmente acessível. Sabido que o custo do processo e a própria inaptidão eventual dos cidadāos para reconhecimento dos seus direitos podem constituir um concreto e grave obstáculo ao acesso desses à jurisdição, como lembra Luiz Guilherme Marinoni ${ }^{56}$, nossa Constituição assegurou em seu art. $5^{\circ}$, LXXIV, o direito do cidadão à assistência jurídica integral e gratuita ${ }^{57}$, erigindo-o à categoria de direito fundamental, outorgando ao próprio Estado o encargo de destrinchar o efetivo acesso à justiça, com o que constitucionalizou entre nós aquilo que Mauro Cappelletti e Bryan Garth com muita propriedade chamaram de primeira onda renovatória do processo civil ${ }^{58}$. O direito ao processo só

53 Por exemplo, STF, Pleno, AGRSE n. 5.206, rel. Min. Maurício Corrêa, Dl 30.04.04. Na doutrina, porém, há ainda quem se posicione pela inconstitucionalidade da Lei de Arbitragem nesse especial; por todos, nesse sentido, consulte-se Walter Camejo Fitho, "Garantia do Acesso a lustica". In: Alvaro de Oliveira, Carlos Alberto (org), Processo e Constituição. Rio de Janeiro: Forense, 2004, pp. 27/30.

34 Nesse sentido caminha a lição de Eduardo Silva da Silva, "Constituição, Jurisdição e Arbitragem". In: Alvaro de Oliveira, Carlos Alberto (org.), Processo e Constituição. Rio de Janeiro: Forense, 2004, pp. 394/ 400 .

55 Princípios do Processo Civil na Constituição Federal, 5. ed.. Säo Paulo: Revista dos Tribunais, 1999, pp. $99 / 100$.

56 Novas Linhas do Processo Civil, 4. ed.. Sāo Paulo: Malheiros, 2000, p. 20 e seguintes.

57 Sobre o tema, consulte-se, entre outros, José Carlos Babbosa Moreira, "O Direito à Assistência lurídicá. Evoluçāo no Ordenamento Brasileiro de Nosso Tempo". In: Revista da Ajuris. Ponto Alegre: s/ed, 1992, pp. $60 / 75$, п. 55 .

58 Acesso à Justiça. Porto Alegre: Sérgio Antônio Fabris Editor, 1988, p. 31. 
pode ser considerado socialmente efetivo, isto é, efetivo para todos, democraticamente eficiente, se as barreiras prévias ao seu acesso forem vencidas. Nossa Constituição procura superar o custo do processo através, por exemplo, da concessão do benefício da gratuidade judiciária a determinados litigantes ${ }^{59}$, buscando superar a falta de informaçāo jurídica mediante a defensoria pública, cuja missão constitucional é, justamente, "a orientação jurídica e a defesa, em todos os graus, dos necessitados" (art. 134, caput, CRFB).

De postremeiro, lembra a doutrina que o art. $5^{\circ}, X X X V, C R F B$, não se cinge a enunciar a cláusula da inafastabilidade da jurisdição, avançando muito mais além, consagrando em realidade um verdadeiro direito à tutela jurisdicional adequada, tempestiva e efetiva e, em contrapartida, um autêntico dever do Estado de prestar jurisdição com idênticos predicados ${ }^{60}$. Lecionando a propósito do conteúdo do direito à tutela efetiva, refere Luiz Guilherme Marinoni que "o direito à prestação jurisdicional efetiva não pode ser considerado um direito a uma prestação fáctica. Mas também não pode ser visto apenas como i) o direito à técnica processual adequada; ii) o direito de participar por meio de procedimento adequado ou iii) o direito à resposta do juiz. Na verdade, o direito à tutela jurisdicional efetiva engloba esses três direitos, pois exige técnica processual adequada (norma processual), instituição de procedimento capaz de viabilizar a participação (p. ex., ações coletivas) e, por fim, a própria resposta jurisdicional" ${ }^{\prime 61}$. Tal dever de proteção, ademais, grava não só o Estado em sua função legislativa, mas também em sua função jurisdicional, autorizando o juiz a proceder, sempre mediante a observância da garantia do contraditório (e, pois, lealmente), do modo que for mais conveniente para o alcance da tutela jurisdicional adequada, tempestiva e efetiva, concretizando-se, assim, o pleno acesso à jurisdição, móvel que alimenta e anima o art. $5^{\circ}, X X X V$ da nossa Constituição, porque, tudo somado, os direitos fundamentais têm mesmo incidência e aplicação imediata (art. $5^{\circ}, \S 1^{\circ}, \mathrm{CRFB}$ ). Nessa linha, aliás, mostra-se inadequado entender que "só tem direito à tutela jurisdicional aquele que tem razão, não quem ostenta direito inexistente", como ensinava Enrico Tullio Liebman ${ }^{62}$ e como continua a reproduzir a doutrina

\footnotetext{
59 O benefício da gratuidade judiciária vem disciplinado entre nós na Lei n. 1.060, de 1950. Sobre o assunto, entre outros, consulte-se Daniel Francisco Mitidiero, Comentários ao Código de Processo Civil. São Paulo: Memória lurídica Editora, 2004, pp. 198/199, tomo 1; José Carlos Barbosa Moreira, "O Direito à Assistência Jurídica. Evoluçäo no Ordenamento Brasileiro". In: Revista da Ajuris. Porto Alegre: s/ed., 1992, pp. 60/75, n. 55; Araken de Assis, "Benefício da Gratuidade". In: Revista da Ajuris. Porto Alegre: s/ed., 1998, pp. 162/ 200, n. 73 .

wo Sobre o tema, amplamente, Luiz Guilherme Marinoni, Técnica Processual e Tutela dos Direitos. Sảo Paulo: Revista dos Tribunais, 2004, pp. 165/247.

63 Técnica Processual e Tutela dos Direitos. São Paulo: Revista dos Tribunais, 2004, p. 185.

62 Manual de Direito Processual Civil. Rlo de Janeiro: Forense, 1984, p. 147, vol. 1.
} 
dominante no Brasil ${ }^{63}$, porque o núcleo da garantia do acesso à justiça está em predispor a todos aqueles que se afirmam titulares de dada situação de vantagem meios adequados nāo só para efetivação do direito material, mas também para a perseguição dessa situação de vantagem em juízo. Não é só o resultado que importa; importa igualmente o caminho que leva ao resultado. Não conceber o direito à tutela jurisdicional como um direito que grava o processo em toda a sua extensão significa comprimir os desígnios de nosso constituinte, exegese que esbarra, evidentemente, nas diretrizes traçadas pelo constitucionalismo contemporâneo acerca da interpretação dos direitos fundamentais ${ }^{64}$.

O devido processo legal processual brasileiro deve-se desenvolver, necessariamente, obedecendo à garantia do juiz natural. Assim é que, diante do nosso direito constitucional, "ninguém será processado nem sentenciado senāo pela autoridade competente" (art. $5^{\circ}$, LIII), não havendo lugar para instalação de "juízo ou tribunal de exceção" (art. 50, XXXVII) ${ }^{65}$. A maioria das Constituições contemporâneas contempla idêntica garantia (por exemplo, art. 25, primeira parte, Constituição italiana; art. 24, Constituição espanhola; art. 18, Constituição argentina; art. 29, Constituição colombiana; art. 47, Constituição russa).

A garantia do juiz natural envolve, no mínimo, dois aspectos relevantes: a) a independência e a imparcialidade jurisdicional e b) a pré-determinação de critérios específicos para fixação da competência jurisdicional. Juiz natural, pois, é juiz imparcial, independente e competente.

No estado atual da doutrina brasileira, a imparcialidade é considerada como uma característica fundamental do conceito de jurisdiçāo, participando de sua essência ${ }^{66}$. Mauro Cappelletti, aliás, não vacila em considerá-la uma

63 Assim, entre outros, Cândido Rangel Dinamarco, "Tutela Jurisdicional". In: Fundamentos do Processo Civil Moderno, 4. ed.. Săo Paulo: Malheiros, 2001, p. 807, tomo II; José Roberto dos Santos Bedaque, Direito e Processo - Influência do Direito Material sobre o Processo. São Paulo: Mahtheiros, 1995, p. 24; Flávio Luiz. Yarshell, Tutela Jurisdicional. São Paulo: Atlas, 1998, pp. 28/30.

(6) Sobre a interpretação dos direstos fundamentais, consulte-se, fundamentalmente, Paulo Bonavides, Curso de Direito Constitucional, 7. ed., 2. tiragem. São Paulo: Malheiros, 1998, pp. 532/599.

us Sobre o juiz natural, consulte-se, entre outros, Carlos Alberto Alvaro de Oliveira, Do Formalismo no Processo Civil, 2, ed.. São Paulo: Saraiva, 2003, pp. 87/88; Nélson Nery Júnior, Princípios do Processo Civil na Constituição Federal, 5. ed. Säo Paulo: Revista dos Tribunais, 1999, pp. 64/69; Cristiane Catarina de Oliveira Ferreira, "Visão Atual do Princípio do Juiz Natural". In: Alvaro de Oliveira, Całlos Alberto (org.), Processo e Constituição. Rio de Janeiro: Forense, 2004, pp. 95/110; Carlos Augusto Silva, "O Princípio do Juiz Natural e sua Repercussão na Jurisprudencia do Supremo Tribunaí Federal", In: Alvaro de Oliveira, Carlos Alberto (org.), Processo e Constituição. Rio de Janeiro: Forense, 2004, pp. 111/134.

wo Assim, na doutrina brasileira, por todos, Ovídio Araújo Baptista da Silva, Curso de Processo Civil, 5. ed.. Săo Paulo: Revista dos Tribunais, 2000, p. 40, vol. I; na doutrina italiana, por todos, Andrea Proto Pisani, Lezioni di Diritto Processuale Civile, 4. ed.. Napoli: Jovene, 2002, p. 10. Sobre o nosso conceito de jurisdiçăo, consultese Daniel Francisco Mitidiero, Comentários ao Código de Processo Civil. São Paulo: Memória Jurídica Editora, 2004, pp. 51/ 53, tomo I; nesse mesmo sentido, Hermes Zaneti Júnior, "Processo Constitucional: Relaçỏes entre Processo e Constituição". In: Introdução ao Estudo do Processo Civil - Primeiras Linhas de um Paradigma Emergente. Porto Alegre: Sérgio Antônio Fabris Editor, 2004, p. 47, en co-autoria com Daniel Francisco Mitidiero. Ainda assim, observa Giuseppe Capograssi que a "objetividade" do magistrado é mesmo a essenencia do processo jurisdicional ("Giudizio, Processo, Scienza, Verità". In: Rivista di Diritto Processuale. Padova: Cedam, 1950, p. 14, vol. V, parte I). 
das virtudes passivas da atividade jurisdicional, suficiente mesmo para apartar a jurisdição das demais atividades estatais ${ }^{67}$. Nossa Constifuiçäo busca tutelar a imparcialidade e a independência jurisdicional garantindo aos júzes vitaliciedade, inamovibilidade e irredutibilidade de subsídio (art. 95, caput), vedando, logo em seguida, algumas atividades aos membros do Poder Judiciário (art. 95, parágrafo único) ${ }^{68}$. Infraconstitucionalmente, nosso Código de Processo Civil assegura aos jurisdicionados o acesso ao juiz natural erigindo o dever do juiz de abster-se em atuar no feito quando impedido ou suspeito (art. 137), possibilitando às partes igualmente a argüição desses motivos mediante exceção processual (art. 304) ou, no caso específico de impedimento, a qualquer tempo, mediante mero requerimento nos autos ${ }^{69}$. A importância que nossa ordem jurídica dispensa à imparcialidade é tamanha que a decisão jurisdicional proferida por juiz suspeito de impedimento é passível de ação rescisória (art. 485 , II, primeira parte). Aliás, idêntico tratamento, nesse particular, é dispensado à sentença proferida por juiz incompetente (art. 485,11 , in fine).

Juiz natural é juiz competente. Ao contrário do que ocorre em Portugal, em que a "indicação do tribunal competente (...) pertence ao legislador ('margem de livre regulação do legislador')", como noticia josé Joaquim Gomes Canotilho ${ }^{70}$, o direito constitucional brasileiro cuidou de traçar a competência dos órgãos jurisdicionais brasileiros (arts. 102, 105, 108, 109, 114, 124, 125, $\$ 10)$, cumprindo às normas do Código de Processo Civil organizar o tema e, no espaço permitido pela Constituição, definir o que previamente não fora acertado constitucionalmente. Como é óbvio, se a competência deve ser definida previamente à ocorrência da res judicanda, é evidente que o próprio órgão jurisdicional já deve existir ao tempo do fato, com o que, na exigência do juiz competente, se compreende também a exigência de pré-constituição do próprio órgão judiciário, vedando-se, assim, os tribunais de exceção. Tal, aliás, o conteúdo mínimo da garantia do juiz natural no direito italiano, consoante observa Giuseppe Tarzia ${ }^{71}$, vedação que entre nós se encontra formulada expressamente.

Nossa Constituição, ao afirmar que todos são iguais perante a lei (art. $\left.5^{\circ}, 1\right)$, preceito que o nosso legislador infraconstitucional cuidou de colocar sob os cuidados do órgão jurisdicional, determinando ao mesmo que assegure "às partes igualdade de tratamento" (art. 125, 1), firmou no ordenamento jurídico

67 Juizes Legisladores? Potto Alegre: Sérgio Antônio Fabris Editor, 1999, pp. 75/76; Juízes Irresponsáveis? Porto Alegre: Sérgio Antônio Fabris Editor, 1989, p. 33.

6t Nesse sentido, por todos, José Afonso da Silva, Curso de Direito Constitucional Positivo, 14. ed.. São Paulo: Malheiros, 1997, pp. 547/548.

69 Nesse sentido, com as devidas indicaçōes bibliográficas, Daniel Francisco Mitidiero, Comentários ao Código de Processo Civil. São Paulo: Memória Jurídica Editora, 2004, p. 564, tomo l.

71 Lineamenti del Processo Civile di Cognizione, 2. ed.. Milano: Giuffrè, 2002, p. 8. 
brasileiro a garantia da paridade de armas entre os sujeitos do processo ${ }^{72}$. Cuidase de pressuposto para que o contraditório encontre ambiente propício ao seu cabal e pleno desenvolvimento.

O art. 125, I, CPC, tal como já referimos alhures ${ }^{73}$, consagrou a igualdade substancial entre os sujeitos do processo, deferindo ao órgão jurisdicional a tarefa de assegurar essa paridade no curso do procedimento. A propósito do assunto, o legislador português fora mais explícito e preciso ao afirmar que "o tribunal deve assegurar, ao longo de todo o processo, um estatuto de igualdade substancial das partes, designadamente no exercício de faculdades, no uso de meios de defesa e na aplicação de cominaçōes ou de sanções processuais" (art. $3^{\circ}-\mathrm{A}, \mathrm{CPC}$ ). A doutrina peruana, ademais, trabalha essa mesma noção como conteúdo do princípio da socialização do processo, segundo o qual "el juez debe evitar que la desigualdad entre las personas por razones de sexo, raza, religión, idioma o condición social, política o económica, afecte el desarollo o resultado del proceso" (Título Preliminar do Código de Processo Civil peruano, art. $\left.6^{0}\right)^{74}$. Todas essas disposições, no entanto, possuem o mesmo conteúdo normativo e apontam na mesma direção.

Ensina Cândido Rangel Dinamarco que o princípio da igualdade, da paridade de armas, impõe uma dúplice responsabilidade ao Estado, sendo dever dos órgãos legislativos e judiciários não criar desigualdades e neutralizar as que eventualmente existam ${ }^{75}$. Costuma-se referir que a previsão de prazos especiais para a Fazenda Pública e para o Ministério Público contida no art.

72 Sobre o assunto, consultar, na doutrina brasileira, Francisco Glauber Pessoa Alves, $O$ Princípio furidico da Igualdade e o Processo Civil Brasileiro. Rio de Janeiro: Forense, 2003; Nélson Nery Júnior, Princípios do Processo Civil na Constituição Federal, 5. ed.. Săo Paulo: Revista dos Tribunais, 1999, pp. 42/63; Rogério Lauria Tucci e José Rogério Cruz e Tucci, Constituição de 1988 e Processo - Regramentos e Garantias Constitucionais do Processo. Säo Paulo: Saraiva, 1989, pp. 37/59; F. C. Santiago Dantas, "Igualdade perante a Lei e 'Due Process of Law'" In: Problemas de Direito Positivo. Rio de Janeiro: Forense, 1953; Sérgio Luiz Wetzel de Mattos, "O Processo Justo na Constituiçăo de 1988". In: Revista da Ajuris. Porto Alegre: s/ed., pp. 227/230, n. 91; Maristela da Silva Alves, "Princípio da Isonomia Constitucional". In: Alvaro de Oliveira, Carlos Alberto (org. i, Processo e Constituiçäo. Rio de Janeiro: Forense, 2004, pp. 135/149; na doutrina italiana, Giuseppe Tarzia, "Parità delle Armi tra le Parti e Poteri del Giudice nel Processo Civile". In: Problemi del Processo Civile di Cognizione. Padova: Cedam, 1989, p. 311 e seguintes; Nicoló Trocker, "Il Nuovo Articolo 111 della Costituzione e il 'Giusto Processo' in Materia Civile: Profill Generali". In: Rivista Trimestrale di Diritto e Procedura Civile. Milano: Giuffrè, 2001, pp. 396/398, n. 2; mais profundamente, ainda, Alessandro Giuliani, "L'Ordo Judiciarius Medioevale (Riflessioni su un Modello Puro di Ordine Isonomicol". In: Rivista di Diritto Processuale. Padova: Cedan, 1988, pp. 598/614, vol, XLII, patte I; na doutrina portuguesa, António Montalvăo Machado e Paulo Pimenta, O Novo Processo Civil, 4. ed.. Coimbra: Almedina, 2002, p. 28.

73 Daniel Francisco Mitidiero, Comentários ao Código de Processo Civil. São Paulo: Memória Jurídica Editora, 2004, pp. 529/560, tomo I.

76 Sobre o assunto, Juan Monroy Gálvez, Introducción al Proceso Civil. Bogotá: Temis, 1996, pp. 100/102, tomo 1.

75 Instituições de Direito Processual Civil, 3. ed. Sảo Paulo: Matheiros, 2003, p. 208, vol. 1. 
$188, \mathrm{CPC}$, fere a garantia da paridade de armas $^{76}$. Quer nos parecer, no entanto, como já comentamos noutro lugar, que essa previsāo atende "à realidade da complexa vida íntima estatal, cheia de entraves burocráticos, em que os elementos que devem servir de base às manifestações em juízo das precitadas entidades nem sempre se oferecem à mão"77, o que justificaria a existência de prazos mais dilargados para a manifestação desses entes e órgãos. A jurisprudência do Supremo Tribunal Federal, de resto, inclina-se nesse mesmo sentido $^{78}$.

Tido como elemento de legitimação do poder jurisdicional ${ }^{79}$ e mesmo como nota distintiva do conceito de processo contemporâneo ${ }^{80}$, a garantia do contraditório, gravada entre nós no art. $5^{\circ}, \mathrm{LIV}, \mathrm{CRFB}$, representa uma autêntica abertura para participação direta do jurisdicionado no poder estatal, tornando o processo um verdadeiro ambiente de inspiração democrática. Afeiçoado, no direito moderno, à simples bilateralidade da instância ${ }^{31}$, de nítida inspiração liberal, como anota Andrea Proto Pisani ${ }^{82}$, hoje ganha feiçōes ativas, significando direito a conhecer e a participar, "participar conhecendo e participar agindo", consoante ensina Mauro Cappelletti ${ }^{83}$, mais consentâneas ao Estado Democrático Social de Direito erigido pela nossa Constituição. A sua observância era uma marca comum a todo processo civil romano, em todos os seus períodos ("legis actiones", "per formulas" e "cognitio extra ordinem")

76 Assim, entre outros, José S. Sampaio, Os Prazos no Código de Processo Civil, 6. ed.. Săo Pauto: Revista dos Tribunais, 2002, pp. 28/29; Cândido Range! Dinamarco, Instituiçóes de Direito Processual Civil, 3. ed.. São Paulo: Malheiros, 2003, pp. 211/214, vol. I.

7 Daniel Francisco Mitidiero, Comentários ao Código de Processo Civil. São Paulo: Memória Jurídica Editora, 2005, p. 155, tomo Il: nesse mesmo sentido, Luiz Guilherme Marinoni, Novas Linhas do Processo Civil, 4. ed.. São Paulo: Malheiros, 2000, pp. 259/260.

78 Por exemplo, STF, Pleno, Embargos de Divergência nos Embargos Declaratórios no RE n. 194.925/MG, rel. Min. Ilmar Galvăo, j. em 24.03.1999, Df 19.04.2002, p. 59.

79 Assim, por todos, Carlos Alberto Alvaro de Oliveira, "A Gałantia do Contraditório". In: Do Formalismo no Processo Civil, 2. ed.. São Paulo: Saraiva, 2003, p. 237.

so Assim, por todos, Elio Fazzalari, Istituzioni di Diritto Processuale, 8. ed.. Padová: Cedam, 1996, pp. 73/76; "La Dottrina Processualistica Italiana: dall"Azione' al 'Processo' (1864-1994)". In: Rivista di Diritto Processuale. Padova: Cedam, 1994, pp. 915/916, vol. XLIX, parte H; consulte-se, também, o verbete "Procedimento (Teoria Generale)". In: Enciclopedia del Diritto. Milano: Giuffrè, 1986, pp. 819/836, vol. XXXV.

A1 Sobre o histórico do contraditório, consulte-se, entre outros, Nicola Picardi, "ll Principio del Contraddittorio". In: Rivista di Diritto Processuale. Padova: Cedam, 1998, pp. 673/681, parte If; "Audiatur et Altera Pars': Le Matrici Storico-Culturali del Contraddittorio". In: Rivista Trimestrale di Diritto e Procedura Civile. Milano: Giuffrè, 2003, pp. 7/22, n.1; Robert Wyness Millar, Los Principios Formativos del Procedimiento Civil. Buenos Aires: Ediar, 1945, pp. 47/55.

8: "Dell'esercizio dell'azione". In: Allorio, Entico (coord.), Commentario del Codice di Procedura Civile. Torino: UTET, 1973, p. 1086, vol. I, tomo If; mais recentemente, Lezioni di Diritto Processuale Civile, 4. ed.. Napoli: Jovene, 2002, pp. 203/204.

83 "Spunti in Tema di Contraddittorio". In: Studi in Memoria di Salvatore Satta. Padova: Cedam, 1982, p. 211, vol. !.

84 Assim, Max Kaser, Direito Privado Romano. Lisboa: Fundação Calouste Gulbenkian, 1999, p. 428. 
e já na Lei n. VIII, Título III da Terceira Partida de Las Siete Partidas achava assento. Nosso direito reinol, a propósito, fora estruturalmente pensado em função da dialética judiciária, da atuação em contraditório dos sujeitos do processo ("judicium est actum trium personarum", conforme gravado nas Ordenações Afonsinas, Livro III, Tf́tulo XX, $\left.\$ 1^{\circ}\right)$. O direito comum medieval, aliás, tinha a garantia do contraditório como um momento central do juízo, o qual polarizava toda a atuação dos sujeitos do processo, sendo infenso, inclusive, à atuação do Príncipe, porque componente essencial do ordo substantialis ${ }^{85}$, do iustum iudicium, na terminologia de Antônio Manuel Botelho Hespanha ${ }^{86}$.

Em sua dimensão contemporânea, como estima Carlos Alberto Alvaro de Oliveira, "o conteúdo mínimo da garantia do contraditório não se esgota na ciência bilateral dos atos do processo e na possibilidade de contraditá-los, mas faz também depender a própria formação dos provimentos judiciais da efetiva participação das partes. Por isso, para que seja atendido esse mínimo, insta que cada uma das partes conheça as razões e argumentações expendidas pela outra, assim como os motivos e fundamentos que conduziram o órgão judicial a tomar determinada decisão, possibilitando-se sua manifestação a respeito em tempo adequado (seja mediante requerimentos, recursos, contraditas etc.). Também se revela imprescindível abrir-se a cada uma das partes a possibilidade de participar do juízo de fato, tanto na indicação da prova quanto na sua formação, fator este último importante mesmo naquela determinada de ofício pelo órgão judicial. O mesmo se diga no concernente à formação do juízo de direito, nada obstante decorra dos poderes de ofício do órgão judicial ou por imposição da regra iura novit curia, pois a parte não pode ser surpreendida por um novo enfoque jurídico de caráter essencial tomado como fundamento da decisão, sem ouvida dos contraditores ${ }^{\prime 87}$. Muitas legislaçōes estrangeiras, de resto, contemplam a garantia do contraditório com esses generosos contornos (por exemplo, art. 16, CPC francês; $\$ 278,111, \mathrm{ZPO}$ alemã; § 182-A, ZPO austríaca; art. $3^{\circ}, 3, \mathrm{CPC}$ português), induvidosamente inspirados no princípio da cooperação, como de há muito lembra Eduardo $\mathrm{Grasso}^{88}$, presente, dentre outros ordenamentos, no português (art. 266, CPC).

3s Sobre o assunto, fundamentalmente, Alessandro Giuliani, "L'Ordo ludiciarius Medioevale - Riflessioni su un Modelo Puro di Ordine Isonomico". In: Rivista di Diritto Processuale. Padova: Cedam, 1988, pp. 598/ 614, vol. XLII, parte II; Nicola Picardi, "Audiatur et Altera Pars' - Le Matrice Storico-Culturali del Contraddittorio". In: Rivista Trimestrale di Diritto e Procedura Civile. Milano: Giuffrè, 2003, pp. 7/22, n. 1. "Uustiça e Administraçăo entre o Antigo Regime e a Revolução". In: Hespanha, Antônio Manuel Botelho (org.), Justiça e Litigiosidade: História e Prospectiva. Lisboa: Fundação Calouste Gulbenkian, 1992, p. 386.

87 "A Garantia do Contraditório". In: Do Formalismo no Processo Civil, 2. ed.. São Paulo: Saraiva, 2003, p. 238. Sobre o assunto, ainda, Leonardo Greco, "O Princípio do Contraditório". In: Revista Dialética de Direito Processual. São Paulo: Dialética, 2005, pp. 71/79, n. 24.

ss "La Collaborazione nel Processo Civile". In: Rivista di Diritto Processuale. Padova: Cedam, 1966, p. 592, vol. XXI. 
Consequência dessa postura a propósito do tema está em que se obriga o órgão jurisdicional a submeter ao contraditório suas possíveis decisôes, inclusive no que toca à matéria que deva conhecer de ofício ${ }^{89}$. Vale dizer: leva-se o próprio magistrado ao contraditório, ao diálogo, fomentando-se a dialética no processo que, ao fim e ao cabo, é mesmo o método mais adequado para reconstrução do direito na incerteza indissociável do cenário processual ${ }^{90}$. Claro está que, nessa perspectiva, adota-se mesmo um novo referencial teórico para o direito processual civil: abandonam-se os solilóquios de um juiz centrado em seu próprio eu, certo de que a verdade, identificada na "vontade concreta da lei", pode ser descoberta solitariamente (porque "iura novit curia", porque às partes só cabe trazer à relação processual o fato, pertencendo o direito ao julgador - "da mihi factum, dado tibo ius"), assumindo-se, ao revés, o contraditório "come cardine della ricerca dialettica" ${ }^{\prime \prime 1}$, suficiente para o alcance do consenso judiciário e, pois, da justiça no caso concreto ${ }^{92}$. Dessarte, evita-se a surpresa, o juízo de "terza via"93, contribuindo-se para a construção de uma verdadeira cidadania processual, que é mesmo um dos fundamentos da República Federativa do Brasil no tocante ao direito processual civil (art. $1^{\circ}, 11, \mathrm{CRFB}$ ).

Temos que observar, ainda, que a garantia do contraditório pode, por vezes, restar postergada, diferida, sendo essa atitude perfeitamente legítima diante de nossa ordem constitucional. Sendo certo que o processo civil vem dominado pelo conflito incessante e brutal entre seus dois valores fundamentais, o da segurança jurídica e o da efetividade do processo, como não deixaram de notar Carlos Alberto Alvaro de Oliveira ${ }^{94}$, Ovídio Araújo Baptista da Silva ${ }^{95} \mathrm{e}$

89 Nesse sentido, na doutrina brasileira, inclusive corn as indicaçöes bibliográficas de estilo, Daniel Francisco Mitidiero, Comentários ao Código de Processo Civil. São Paulo: Memória Jurídica Editora, 2005, pp. $518 /$ 519, tomo ll; na doutrina italiana, Francesco Paolo Luiso, Diritto Processuale Civile, 3. ed.. Milano: Giuffrè, 2000 , p. 30, vol. 1; sobre o temá, consulte-se, ainda, Sergio Chiarloni, "Questioni Rilevabill d'Ufficio, Diritto di Difesa e 'Formalismo delle Garanzie'" In: Rivista Trimestrale di Diritto e Procedura Civile. Milano: Giuffrè, 1987, pp. 569/584, parte II.

90 Nesse sentido, Michel Villey, Filosofia do Direito. Säo Paulo: Martins Fontes, 2003, p. 280.

21 Nicola Picardi, "Il Principio del Contraddittorio". In: Rivista di Diritto Processuale. Padova: Cedam, 1998, pp. 679/681, partell; "Audiatur et Altera Pars': Le Matrici Storico-Culturali del Contraddittorio". In: Rivista Trimestrale di Diritto e Procedura Civile. Milano: Giuffrè, 2003, pp. 21/22, n. 1.

92 Que, tudo sopesado, é mesmo o fim último do processo civil contemporâneo, conforme Carlos Alberto Alvaro de Oliveira, "O Processo Civil na Perspectiva dos Direitos Fundamentais". In: Do Formalismo no Processo Civil, 2. ed.. São Paulo: Saraiva, 2003, p. 270. Há, aliás, uma necessidade crescente de pensar o Direito diante do caso concreto, dada a insuficiencia dos esquemas positivos, bem observada igualmente por Luiz Guitherme Marinoni, Técnica Processual e Tutela dos Díreitos. São Paulo: Revista dos Tribunais, 2004, p. 214.

93 Sobre o tema, entre outros, Giuseppe Tarzia, Lineamenti del Processo Civile di Cognizione, 2. ed.. Milano: Giuffè, 2002, pp. 10/11; Luigi Montesano, "La Garanzia Costituzionale del Contraddittorio e i Giudizi di Terza Via'". In: Rivista di Diritto Processuale. Padova: Cedam, 2000, p. 929 e seguintes.

94 "O Processo Civil na Perspectiva dos Direitos Fundamentais". In: Do Formalismo no Processo Civil, 2. ed.. Sảo Paulo: Saraiva, 2003, p. 270.

95 Curso de Processo Civil, 3. ed.. Săo Paulo: Revista dos Tribunais, 2000, p. 20, vol. Ill. 
Teori Albino Zavascki ${ }^{96}$, as soluções de compromisso entre ambos se oferecem como uma realidade inafastável do campo forense. Escrevendo sobre a possibilidade de antecipação da tutela "inaudita altera parte", em que se franqueia a efetivação do direito provável sem a observância prévia do contraditório, assevera Luiz Guilherme Marinoni que tal expediente é de todo constitucional, na medida em que a jurisdição de urgência é um componente indissociável do acesso à justiça, não valendo argumentar com eventual ofensa ao contraditório como óbice à efetivação de medidas desse jaez, porquanto igualmente atende à garantia do contraditório a sua realização postecipada ${ }^{97}$. Atende à nossa garantia constitucional do contraditório, portanto, além do contraditório prévio, também o contraditório diferido, que é aquele que se realiza, na mesma relação processual, em momento posterior à efetivação de dada medida contra quem se deve dar a possibilidade de participar posteriormente.

Finalmente, igualmente se mostra legítimo o contraditório eventual, que é aquele que se realiza, por exemplo, com a execução de um título executivo extrajudicial, em que só se efetiva o contraditório mediante a iniciativa do executado e em um processo diferente daquele em que os atos executivos sāo efetuados. À guisa de diferenciar o contraditório prévio e o diferido do contraditório eventual, ensina Ovídio Araújo Baptista da Silva que "enquanto no chamado contraditório prévio e no contraditório diferido, as posiçōes das partes não se alteram, em virtude da aplicação do princípio - o autor continua autor e o réu, como réu, haverá de contestar a ação -, no eventual aquele que figurara inicialmente como autor irá tornar-se demandado, na ação plenária subseqüente ${ }^{\prime \prime 98}$. A técnica do contraditório eventual, de resto, é um importante expediente de sumarização material, concorrendo, pois, para outorgar efetividade à tutela jurisdicional, mercê da redução do campo do litígio ${ }^{99}$.

Prevista juntamente com a garantia do contraditório em nossa Constituição encontra-se a garantia da ampla defesa, com os meios e recursos a ela inerentes (art. $5^{\circ}$, LIV, CRFB). Trata-se da garantia de "plenitude da defesa" no processo civil, como anotam Rogério Lauria Tucci e José Rogério Cruz e Tucciriog.

96 Antecipação da Tutela, 2. ed.. São Paulo: Saraiva, 1999, pp. 61/65.

97 A Antecipação da Tutela, 8. ed.. Săo Paulo: Malheiros, 2004, pp. 187/189. Nesse mesmo sentido a lição de Carlos Alberto Alvaro de Oliveira, "A Garantia do Contraditório". In: Do Formalismo no Processo Civil, 2. ed. Săo Paulo: Saraiva, 2003, pp. 240/241. os dois conceitos: o primeiro conceme à exclusão de parcelas do direito material da cogniçăo do júzo, ao passo que o segundo atine à abreviaçăo do procedimento. A sumariedade formal diz respeito à forma do processo, referindo-se a sumariedade material a situaçăo litigiosa nesse afirmada, conforme, por todos, Carlos Alberto Alvaro de Oliveira, Comentários ao Código de Processo Civil, 6. ed.. Rio de janeiro: Forense, 2002, p. 17, vol. Vill, tomo Il, em co-autoria com Galeno Lacerda.

100 Constituição de 1988 e Processo - Regramentos e Garantias Constitucionais do Processo. São Pauto: Saraiva, 1989, p. 60. 
A doutrina costuma ligar a garantia da ampla defesa ao réu, ao demandado, porque o conteúdo semântico do termo "defesa" induz à idéia de resistência a algo, de bloqueio a um golpe ${ }^{101}$. Em geral, a doutrina aponta em seu conteúdo o direito à informação, o direito ao contraditório e o direito à prova $^{102}$. Mais analiticamente, ensina Alex Carocca Pérez que a garantia constitucional da ampla defesa implica, necessariamente, a possibilidade de alegar, provar, contradizer e ver suas alegaçôes e provas sopesadas no quando do julgamento do feito ${ }^{103}$. Com a sua expansão para esfera processual civil, tem-se recomendado uma interpretação o mais abrangente possivel ${ }^{104}$, a fim de que nenhum processo escape de sua disciplina.

Porém, como bem observa José Maria Rosa Tesheiner, a expressão "ampla defesa", consagrada pela nossa Constituição, é "ampla demais", servindo apenas em termos para o direito processual civil ${ }^{105}$. Inicialmente prevista em nosso direito constitucional tăo-somente a propósito do direito processual penallo6, nosso legislador constituinte estendeuna igualmente ao processo civil, incorrendo em indevida assimilação ${ }^{107}$, fruto, como bem percebeu Daisson Flach ${ }^{108}$, de nossa "modernidade jurídica". Com efeito, prevendo-se a ampla defesa com os meios e recursos a ela inerentes para todo o direito processual civil brasileiro, nossa Constituição parece ter proscrito de nosso horizonte constitucional qualquer possibilidade de processo jurisdicional que nāo seja plenário do ponto de vista cognitivo, como leciona Ovídio Araújo Baptista da Silva ${ }^{109}$. Certo que essa eliminação simplesmente não pode se dar, tendo em conta a exigência de que a tutela jurisdicional seja adequada, tempestiva e efetiva (art. $5^{\circ}, X X X V, C R F B$ ) e que um dos notórios meios com que se alcançam tais predicados à função judicial é justamente a sumarização das demandas,

101 Assim, na doutrina brasileira, Ruil Portanova, Princípios do Processo Civil, 2. tiragem. Porto Alegre: Livraria do Advogado, 1997, p. 125; na doutrina Chilena, Alex Carocca Perez, "Garantía Constitucional de la Defensa". In: Revista Peruana de Derecho Procesal. Lima: Estudio Monroy Abogados, 1998, p. 370, vol. Il.

102. Assim, Rogério Lauria Tucci e losé Rogério Cruz e Tucci, Constituição de 1988 e Processo - Regramentos e Garantias Constitucionais do Processo. Sảo Paulo: Saraiva, 1989, p. 61.

103 "Garantía Constitucional de la Defensa". In: Revista Peruana de Derecho Procesal. Litma: Estudio Monroy Abogados, 1998, pp. 373/374, vol. Il.

$: 04$ Assim, Rosemiro Pereira Leal, Teoria Geral do Processo, 5. ed.. Säo Paulo: Thompson-10B, 2004, p. 104.

70s Elementos para uma Teoria Geral do Processo. Săo Paulo: Saraiva, 1993, pp. $45 / 46$.

106 Como se pode conferir no preciso histórico traçado por Pontes de Miranda, Comentários à Constituição de 1967 com a Emenda n. 1, de 1969, 2. ed. Säo Paulo: Revista dos Tribunais, 1971, pp. 232/233, tomo V.

107 Nesse sentido, por todos, Ovídio Araújo Baptista da Silva, "A 'Plenitude de Defesa' no Processo Civil". In: Da Sentença Liminar à Nulidade da Sentença. Rio de Janeiro: Forense, 2001, pp. 107/127.

108 "Processo e Realização Constitucional: a Construção do 'Devido Processo". In: Amaral, Guilherme Rizzo e Carpena, Márcio Louzada (coords.), Visones Críticas do Processo Civil Brasileiro - Uma Homenagem ao Prof. Dr. José Maria Rosa Tesheiner. Porto Alegre: Livratia do Advogado, 2005, p. 23.

109 "A 'Plenitude de Defesa' no Processo Civil". In: Da Sentença Liminar à Nulidade da Sentença. Rio de laneiro: Forense, 2001, p. 109. 
como anota Andrea Proto Pisani110, cumpre encontrar uma solução de compromisso entre ambas normas constitucionais, que deverá ser aferida em concreto, à vista das especificidades inerentes a essa ou aquela situação carente de tutela e o respectivo procedimento destinado à sua proteção.

A publicidade é uma das características do devido processo legal processual brasileiro (arts. $5^{\circ}$, LIV , LX e 93, IX, CRFB), constituindo um dos pilares constitucionais de nosso formalismo processual ${ }^{\natural 11}$. Como se vê, a agonia de Joseph K., descrita com mão de mestre por Franz Kafka em seu célebre $O$ Processo ${ }^{112}$, pela inacessibilidade dos atos processuais não teria lugar dentro do processo civil brasileiro, assim como também não teria, em regra, no processo civil lusitano (art. 167) e no processo civil italiano (art. 128, primeira parte).

A garantia da publicidade dos atos processuais prende-se, hodiernamente, à necessidade de fiscalização pelos participantes do processo e, em certos casos, também pelo povo em geral do conteúdo do que se faz em juízo. Não é à toa, pois, que Michele Taruffo a insere como um dos elementos essenciais à idéia de administração democrática da Justiça ${ }^{113}$. Velase, através da publicidade, a transparência da Justiça (como bem lembra José Carlos Barbosa Moreira, "não basta que se faça justiça: é preciso que se veja que está sendo feita justiça" $\left.{ }^{114}\right)$. Sobre ser uma garantia processual ligada à oralidade, como bem assinalam Robert Wyness Millar ${ }^{115}$, Egas Dirceu Moniz de Aragão ${ }^{176}$, Jefferson Carús Guedes ${ }^{17}$ e José Cretella Neto ${ }^{118}$, é um postulado político, coarctado à própria idéia de Estado Democrático e Social de Direito (art. $1^{\circ}$, caput, CRFB), a permitir o controle da opinião pública nos serviços

110 Lezioni di Diritto Processuale Civile, 4. ed. Napoli: Jovene, 2002, p. 548.

11: Do Formalismo no Processo Civil, 2, ed. São Paulo: Saraiva, 2003, pp. 79/80.

312 Franz Kafka, O Processo, 6, reimpressāo. Sảo Paulo: Companhia das Letras, 2003, p. 142.

31.3 "Il Significato Costituzionale dell'Obbligo di Motivazione". In: Dinamarco, Cândido Rangel; Grinover, Ada Pellegrini; Watanabe, Kazuo (coord.). Participação e Processo. Săo Paulo: Revista dos Tribunais, 1988, p. 38. Igualmente assinalando esta estreita conexäo entre publicidade do processo e democracia, Eduardo Couture, "Las Garantías Constitucionales del Proceso Civil". In: Estudios de Derecho Procesal Civil. Buenos Aires: Ediar Editores, 1948, pp. 20/21, tomo I; Enrique Vescovi, "Hacia un Proceso Civil Universal". In: Revista de Processo. Sāo Paulo: Revista dos Tribunais, 1999, p. 182, n. 93 . No mais, Mauro Cappelletli insere mesmo a publicidade do processo e a conseqüente publicidade das decisỏes jurisdicionais como um dos fatores que induzem à responsabilizaçào social dos juízes (Juízes Irresponsáveis? Porto Alegre: Sérgio Antônio Fabris Editor, 1989, p. 47).

114 "A Justiça no Limiar de Novo Século". In: Revista Forense. Rio de Janeiro: Forense, 1992, p. 73, n. 319. Deste mesmo autor, sobre o tema, consulte-se ainda "Publicité et Secret du Delibere dans la Justice Brésilienne". In: Temas de Direito Processual. São Paulo: Saraiva, 1989, pp, 193/204, Quarta Série.

१1.5 Los Principios Formativos del Procedimiento Civil. Buenos Aires: Ediar, 1945, p. 185.

¿16 Comentários ao Código de Processo Civil, 9. ed. Rio de Janeiro: Forense, 1998, p. 14, vol. It.

1:7 O Principio da Oralidade - Procedimento por Audiencias no Direito Processual Civil Brasileiro. Săo Paulo: Revista dos Tribunais, 2003, pp. 77/80.

118 Fundamentos Principiológicos do Processo Civil. Rio de Janeiro: Forense, 2002, p. 100. 
da Justiça ${ }^{119}$. Historicamente, teve sua forma mais pura no direito germânico primitivo, pelo dever de assistirem os homens livres aos julgamentos e participarem da administração da justiça. Em Roma também já havia publicidade geral, sem apresentar, no entanto, a mesma conotação de justiça popular construída no primitivo processo alemão ${ }^{120}$. Com o correr do tempo, como narra Pontes de Miranda, "os imperadores, com as basilicae, foi tirado o direito das partes à comparência às sessões (século V). A cortina - vela velou os procedimentos, as discussões; de secretum ocio o nome secretariuem para designar a sala mais ao fundo, menos acessivel. $\grave{A}$ frente, os serviços do juízo ou tribunal; mais à frente, os canceli, que separavam de tudo aquilo o público. Era o sinal de decadência, com a exceção para os honorati, pessoas das classes privilegiadas, que até sentavam ao lado dos juízes. Restava a prova testemunhal em presença das partes; porém as perguntas eram feitas pelo juiz. No entanto, o direito romano tivera o interrogatório por perguntas e reperguntas formuladas pelos advogados (M. A. von Bethmann Hollweg, Der Civilprozess des gemeinen Rechts, III, 277). O direito canônico, rompendo com o princípio da publicidade, ainda especial (perante as partes), quanto à prova testemunhal, tornou-a, já no século XII, só em presença do juiz e do secretário. O exemplo foi desgraçadamente seguido em juízos seculares (C. J. A. Mittermaier, Über das Teutschrechtliche Verfahren, Archiv für die Civilistische Praxis, V, 69 s.). A exclusão dos estranhos faz de publicidade especial, em lugar de geral, a prova testemunhal. Foi esse meiotermo que passou, em 1806, o direito francês, imitado pelas leis de outros povos. Outros, como a Espanha, conservaram a inquisição em segredo até $1881^{\prime \prime 121}$.

Publicidade, em direito processual civil, pode ser geral ou especial. Se a publicidade é geral, tal como é a regra em nosso ordenamento jurídico, então a todos é franqueado acesso ao que se faz em juízo (a audiência de instrução e julgamento é, via de regra, pública, art. 444, CPC); se a publicidade

lis Neste sentido, na doutrina brasileira, Moacyr Amaral Santos, Primeiras Linhas de Direito Processual Civil, 10. ed.. São Puulo: Saraiva, 1983, p. 286, vol. I; Cláudia Marlise da Silva Alberton, Publicidade dos Atos Processuats e Direito à Informaçâo. Rio de Janeiro: Aide Edłtora, 2000, p. 48; José Milton da Silva, Teoria Geral do Processo, 2. ed. Rio de Janeiro: Forense, 2003, p. 49; Patrícia Teixeira de Rezende Flores e. Andréa Pécora, "Princípio da Publicidade: Restriçöes". In: Sérgio Gillberto Porto (org.), As Garantais do Cidadão no Processo Civil - Relações entre Constituição e Processo. Porto Alegre: Livraria do Advogado, 2003, pp. 97/123; na doutrina argentina, Juan Carlos Bavasso Roffo, Publicidad del Proceso. Buenos Aires: Abeledo-Perrot, 1961, p. 39; na doutrina peruana, Juan Monroy Gálvez, Introducción al Proceso Civil. Bogotá: Temis, 1996, p. 84, tomo 1.

120 Tudo conforme Pontes de Miranda, Comentários ao Código de Processo Civil, 5. ed.. Rio de Janeiro: Forense, 1997, p. 54, tomo le Robert Wyness Millar, Los Principios Formativos del Procedimiento Civil. Buenos Aires: Ediar, 1945, pp. $187 / 190$.

121 Comentários ao Código de Processo Civil, 5. ed. Rio de Janeiro: Forense, 1998, pp. 54/55, tomo 1. Lição, ademais, prestigiada por Carlos Alberto Alvaro de Oliveira, Do Formalismo no Processo Civil, 2. ed.. São Pato: Saraiva, 2003 , pp. $79 / 80$. 
é especial, tudo há de se passar com restrição ao público, cingindo-se a publicidade aos participantes do processo (caso dos processos que se desenvolvem sob o segredo de justiça, art. 155, $\mathrm{CPC}^{122}$ ), salvo a demonstração de interesse jurídico por terceiro. Fala-se também em publicidade imediata, que é a co-presença facultada à prática dos atos processuais, e em publicidade mediata, que é a possibilidade de se alcançar a qualquer cidadão comunicação do ocorrido no feito (direito de requerer certidões, por exemplo). Nosso Código contempla e entrelaça, aqui e ali, todas estas acepções da publicidade processual ${ }^{123}$.

Dentro do aspecto de abrangência do devido processo legal processual brasileiro, todas as decisões do Poder Judiciário deverão ser motivadas (art. 93, IX, CRFB). Acaso não o sejam, sobra-thes a pecha de invalidade ${ }^{124}$. Nosso Código de Processo Civil refere que "as sentenças e acórdãos serão proferidos com observância do disposto no art. 458; as demais serão fundamentadas, ainda que de modo conciso" (art. 165). Cumpre ao juiz decidir a causa de maneira fundamentada (art. 458, II, CPC), rejeitando, no todo ou em parte, o pedido formulado pelo autor. Nos casos de extinção do processo sem julgamento de mérito, o juiz decidirá em forma concisa (art. 459, CPC) ${ }^{125}$. Tal como a publicidade, a motivação é um elemento essencial e inarredável de uma administração democrática da Justiça ${ }^{126}$.

O dever de motivação das decisões judiciais acompanhamnos de longa data, sendo possivel remontá-lo às velhas partidas espanholas (Las Siete Partidas, Terceira Partida, Título IV, Lei VI), veículo que disseminou o direito romano em Portugal à época do renascimento desse ${ }^{127}$, passando daí às Ordenações Afonsinas (ainda que

${ }_{122}$ Sobre o segredo de justiça e sua disciplina no processo civil brasileiro, consulte-se Daniel Francisco Mitidiero, Comentários ao Código de Processo Civil. Sâo Paulo: Memória Juridica Editora, 2005, pp. 34/37, tomo H.

123 Sobre o assunto, consulte-se Pontes de Miranda, Comentários ao Código de Processo Civil, 5a ed.. Rio de Janeiro: Forense, 1997, p. 54, tomo i; Comentários ao Código de Processo Civil, 4a ed.. Rio de Janeiro: Forense, 1997, p. 51, tomo II; Robert Wyness Millar, Los Principios Formativos del Procedimiento Civil. Buenos Aires: Ediar, 1945, p. 187.

\$2. Sobre o grave problema das invalidades processuais, com as devidas indicaçōes bibliográficas, consulte-se Daniel Francisco Mitidiero, Comentários ao Código de Processo Civil. Sāo Paulo: Memória Juridica Editora, 2005, pp. 382/425, tomo Il; "O Problema da Invalidade dos Atos Processuais no Direito Processual Civil Brasileiro Contemporâneo". In: Amaral, Guilherme Rizzo e Carpena, Márcio Louzada (coords.), Visōes Críticas do Processo Civil Brasileiro - Uma Homenagem ao Prof. Dr. José Maria Rosa Tesheiner. Porto Alegre: Livraria do Advogado, 2005, pp. 55/74.

22. Para um panorama historico e comparativo acerca do dever de motivaçáo sentencial, consulte-se, por todos, Michele Taruffo, La Motivazione della Sentenza Civile. Padova: Cedam, 1975, pp. 319/370.

:26 Nesse sentido, Michele Taruffo, "I! Significato Costituzionale dell'Obbligo di Motivazione". In: Dinamarco, Cândido Rangel; Grinover, Ada Pellegtini e Watanabe, Kazuo (coords.), Participação e Processo. Săo Paulo: Revista dos Tribunais, 1988, pp. 41/42; sobre o assunto, consulte-se, ainda, Daniel Ustárroz, "A Democracia Processual e a Motivaçāo das Decisōes Judiciais". In: Porto, Sérgio Gilberto (org.), As Garantias do Cidadão no Processo Civil - Relaçôes entre Constituição e Processo. Porto Alegre: Livraria do Advogado, 2003, pp. 125/145.

127 Sobre o assunto, por todos, Nuno l. Espinosa Gomes da Silva, História do Direito Português. Lisboá: Fundação Calouste Gulbenkian, 1985, pp. 158/162, vol.1. 
de maneira implícita, Livro III, Título LXIX, pr.), às Manuelinas e às Filipinas (em ambas de forma expressa, respectivamente, Livro III, Título L, $\$ 6^{\circ}$ e Livro III, Título LXVI, $\S 7^{\circ}$ ), como observa Carlos Alberto Alvaro de Oliveira ${ }^{128}$. Constitucionalmente, porém, é inovação que se deve à Constituição vigente ${ }^{129}$, ainda que se pudesse sacá-lo, implicitamente, da previsão da existência de um Estado de Direito, como bem demonstrou certa feita José Carlos Barbosa Moreira ${ }^{\sharp 0}$.

Com efeito, existe um nexo imediato entre o acesso à justiça, entre a inafastabilidade da jurisdiçāo e a garantia da motivação das decisões judiciais ${ }^{131}$. Sem motivação, não há que se falar em processo justo e em controle das decisões judiciais; não há, pois, democracia processual. À sentença carente de motivação não se reconhece, pois, um legítimo exercício de poder jurisdicional nos quadros do Estado Democrático de Direito ${ }^{132}$.

Dessarte, toda decisão jurisdicional, por força constitucional, tem de ser motivada, tendo em conta a necessidade de controle do poder jurisdicional por parte da sociedade, pendor de legitimidade dessa funçāo em um Estado Democrático de Direito (art. $1^{\circ}, \mathrm{CRFB}$ ). Não é à toa, pois, que Nicola Picardi considera que, contemporaneamente, o poder jurisdicional se caracteriza justamente por ser um poder limitado e controlável, um poder que se aloca entre o poder vinculado e o poder absoluto ${ }^{133}$. Essa motivação, aliás, tem de ter um conteúdo mínimo essencial, sem o qual não se reputa atendida essa ordem constitucional. A síntese desse conteúdo mínimo normalmente ocorre quando o julgador logra: a) individualizar os fatos, as normas jurídicas incidentes e aplicáveis ao caso concreto, a juridicização dos fatos e as suas conseqüências jurídicas; b) contextualizar os nexos de implicação e de coerência entre os enunciados fáctico-legais e c) justificar esses mesmos enunciados racionalmente, reportando-se ao ordenamento jurídico ${ }^{134}$. Não satisfaz os rigores do art. 93, IX, CRFB, por exemplo, a simples menção às normas legais, ou aos jargões contidos nas mesmas, sem qualquer enfrentamento da situação concreta trazida à consideração judicial ${ }^{135}$, praxe infelizmente comum entre nós ${ }^{136}$.

123 Do Formalismo no Processo Civit, 2. ed.. Säo Paulo: Saraiva, 2003, p. 88.

129 Nesse sentido, Rogério Lauria Tucci e José Rogério Cruz e Tucci, Constituição de 1988 e Processo Regramentos e Garantias Constitucionais do Processo. São Paulo: Saraiva, 1989, pp. 78/79.

130 "A Motivação das Decisóes como Garantia Inerente ao Estado de Direito". in: Temas de Direito Processual, 2. ed. São Paulo: Saraiva, 1988, pp. 83/95, Segunda Série.

13: Nicolò Trocker, Processo Civile e Costutuzione. Milano: Giuf́ffrè, 1974, p. 462.

132 Michele Taruffo, La Motivazione della Sentenza Civile. Padova: Cedam, 1975, pp. 319/320.

133 "La Vocazione del Nostro Tempo per la Giurisdizione". In: Rivista Trimestrale di Diritto e Procedura Civile. Milano: Giufftè, 2004, pp. 56/57, n. 1 .

134 Michele Taruffo, La Motivazione della Sentenza Civile. Padova: Cedam, 1975, p. 467.

135 Assim, por todos, Nélson Nery Júnior, Príncípios do Processo Civil na Constituição Federal, 5 . ed.. São Paulo: Revista dos Tribunais, 1999, p. 176.

i.35 Para um maior aprofundamento da questão da motivaçăo da sentença e suas eventuais patologias, consultese, na doutrina brasileira, por todos, Athos Gusmão Carneiro, "Sentença Malfundamentada e Sentença NãoFundamentada. Conceitos. Nulidades". In: Revista da Ajuris. Porto Alegre: s/ed., 1995, pp. 5/12, n. 65. 
Enfeixando a disciplina do devido processo legal processual entre nós, garante-se a todos a duração razoável do processo ${ }^{137}$. Deveras, nossa Constituição assegura a todos, no àmbito judicial e administrativo, "a razoável duração do processo e os meios que garantam a celeridade de sua tramitação" (art. 5०, LXXVII1), alinhando-se em conteúdo, pois, com outras Constituições contemporâneas qque prevêem a mesma garantia (por exemplo, Constituição portuguesa, art. 20, n. 3; Constituição italiana, art. 111, segunda parte). Em termos semelhantes, a Constituição espanhola assegura um processo sem dilações indevidas (art. 24, segunda parte).

A propósito do direito italiano, ensina Nicolò Trocker que o art. 111, segunda parte da Constituição italiana prevê o princípio da tempestividade da tutela jurisdicional ${ }^{138}$. Quanto ao direito brasileiro, outro não é o estado de coisas que o nosso art. $5^{\circ}$, LXXVIII, CRFB, visa a alcançar: asseguramse um processo de duração razoável com os meios que garantem a celeridade de sua tramitação justamente para que se adjudique aos sujeitos do processo uma tutela jurisdicional tempestiva.

Nossa Constituição, no art. $5^{\circ}$, LXXVIII, apenas explicita o que antes já poderíamos retirar do art. $5^{\circ}, X X X V$ : a tutela jurisdicional deve ser tempestiva, porque justiça que tarde acode é manifesta injustiça. A doutrina italiana, aliás, antes mesmo da modificação constitucional que introduziu a garantia da "durata ragionevole" no âmbito do processo já igualmente a retirava da cláusula constitucional do acesso à jurisdição (art. 24) ${ }^{139}$.

Ao contrário do que sucede na Itália, diante do ordenamento jurídico brasileiro a garantia da razoabilidade da duração do processo é plenamente sindicável pelo Poder Judiciário. Nossa Constituição desde logo outorga direito a um processo tempestivo. Essa tomada de posição não é isenta de conseqüências: enquanto que na ltália a Corte Constitucional "non può sindicare la durata del singolo processo ma esclusivamente disposizioni che prevedano tempi lunghi, inutili passaggi di atti da un organo all'altro, formalità superflue, non giustificate da garanzie difensive ${ }^{\prime \prime 140}$, o que só se mostra possível à Corte européia, o Poder Judiciário brasileiro pode aquilatar, caso a caso, a duração razoável do processo. Explica-se a diferença entre os sistemas: a Constituição

1.37 Sobre o assunto, na doutrina brasileira, losé Carlos Basbosa Moreira, "A Duração dos Processos: Alguns Dados Comparativos". In: Revista da Ajuris. Porto Alegre: s/ed., 2005, pp. 151/159, n. 98; Gustavo de Medeiros Melo, "A Tutela Adequada na Reforma Constitucional de 2004". In: Revista de Processo. São Paulo: Revista dos Tribunais, 2005, pp. 76/110, n. 124.

38 "Il Nuovo Articolo 111 della Costituzione e il 'Giusto Processo' in Materia Civile: Prófili Generali". In: Rivista Trimestrale di Diritto e Procedura Civile. Milano: Giuffrè, 2001, p. 403, n. 2.

139 Sobre o assunto, Giuseppe Vignera, "Le Garanzie Costituzionali del Processo Civile alla luce del 'Nuovo' art. 111 Cost.". In: Rivista Trimestrale di Diritto e Procedura Civile. Milano: Giuffrè, 2003, pp. 1221/1240, n. 4.

140 Sergio Chiarloni, "Il Nuovo art. 111 e il Processo Civile". In: Rivista di Diritto Processuale. Padova: Cedam, 2000, p. 1032, n. 4 . 
italiana prevê que a lei assegurará a "ragionevole durata", ao passo que a Constituição brasileira assegura a duração razoável, o que é diretamente assegurado, também, pelo art. $6^{\circ}$ da Convenção Européia dos Direitos do Homem. A sindicabilidade da matéria entre nós é manifesta.

A definição da razoabilidade da duração do processo exige que o julgador observe alguns critérios para aferição do atendimento à garantia constitucional. Giuseppe Tarzia, lembrando algumas diretrizes traçadas pela Corte di Strasburgo a respeito do tema, refere que a duração razoável do processo deve ser aquilatada à luz da complexidade da causa, do comportamento do autor durante o procedimento e do comportamento das autoridades judiciária, administrativa e legislativa ${ }^{14}$. Entre nós, outro bom parâmetro para aferição é fornecido expressamente pela nossa Constituição: saber se os meios que garantem a celeridade na tramitação do feito estavam, por exemplo, predispostos pelo ordenamento jurídico. Uma possível conseqüência da violação da garantia da tempestividade do processo é a indenizabilidade, via propositura de "açäo" processual, o que pode se dar tanto contra a União como contra os Estados, conforme o caso. Outra, é a sindicabilidade dos atos processuais que importem em delonga insuportável para parte (por exemplo, a prática comum no foro dos magistrados de reservarem-se para analisar o pedido de antecipação de tutela tão-somente após a contestação do réu), consoante já decidiu o Tribunal de Justiça do Estado do Rio Grande do Sul ${ }^{142}$.

Oportuno, aliás, trazer à colação as judiciosas considerações constantes do voto do eminente relator, Dr. Pedro Luiz Pozza, processualista de escol: "do mesmo modo, afasto a preliminar de descabimento do agravo, porque o juiz a quo não teria indeferido a antecipação da tutela, mas simplesmente postergado seu exame para após a contestação da agravada. Ora, ainda que se possa admitir em casos especiais que o juiz, antes de proferir a decisão antecipatória da tutela, aguarde a manifestação do réu, há outros em que a situação fática não admite que isso seja feito. Ou seja, haverá hipóteses em que tal postura do juiz configura um verdadeiro indeferimento da medida postulada, pela urgência da parte em obter o provimento postulado - seja para imediato cumprimento, seja para interpor recurso. Não se pode de modo nenhum esquecer que o direito à jurisdição de urgência tem dimensão constitucional entre nós (art. $5^{\circ}, X X X V$ e LXXVHII), como salienta Luiz Guilherme Marinoni (A Antecipação da Tutela, 8. ed.. São Paulo: Malheiros, 2004, pp. 155/166), assim como tem diante do direito italiano (art. 111 da Constituição

14: Lineamenti del Processo Civile di Cognizione, 2. ed.. Milano: Giuffrè, 2002, p. 13. Outras informações sobre o assunto podem ser encontradas em Antonio Didone, "Apuntes sobre la Duración Razonable del Proceso Civil". In: Revista Peruana de Derecho Procesal. Limat: Estudio Monroy Abogados, 2004, pp. 185/ 197, n. VII.

142 TJ-RS, 18a Camara Civel, AIAGi n. 70010827772, rel. Pedro Luiz. Pozza, j. em 17.02,2005. 
italiana), como abaliza a doutrina (por todos, Andrea Proto Pisani, Lezioni di Diritto Processuale Civile, 4. ed.. Napoli: Jovene, 2002, p. 596), sendo, ademais, um autêntico direito fundamental, perspectiva que coloca a problemática ora discutida em um outro plano de compreensão, escapando do alcance puramente infraconstitucional. Se o autor tem direito a obter do Poder Judiciário uma resposta ao seu pedido, como de fato tem (art. $5^{\circ}, \mathrm{XXXV}, \mathrm{CF}$ ), e se essa resposta não pode ignorar a passagem do tempo (art. $5^{\circ}, \mathrm{LXXVIII,CF}$, redação da $\mathrm{EC}$. 45/2004), que por si só é um fator de dano ao autor (no mínimo de um 'dano marginale', como anota italo Andolina, 'Cognizione' ed 'Esecuzione Forzata' nel Sistema della Tutela Giurisdizionale. Milano: Giuffrè, 1983, p. 17), evidente que se mostram suscetíveis de sindicalização por essa Corte eventuais decisōes do juiz de primeiro grau que fazem tábua rasa do tempo no processo. Esse, por expressa disposição constitucional, é plenamente judicializável, porque a sua exata composição no processo é um elemento impossível de ser eliminado do devido processo legal processual brasileiro (art. 5', LIV, CF), assim como é de outros ordenamentos jurídicos (como o Espanhol, em que o art. 24, segunda parte, Constituição, em que se assegura um processo 'sem dilações indevidas'). Ora, é evidente que, ao postergar a apreciação do pedido de antecipação de tutela o dd. magistrado de primeiro grau dilatou indevidamente o processo, afrontando o direito do autor a um processo tempestivo (art. $5^{\circ}$, LXXVIII, CF, redação da EC n. 45/2004). Importa lembrar, ainda, que pelo regime de fundamentalidade formal e material do direito fundamental a um processo justo é équo (art. $5^{\circ}$, LIV , CF), que engloba sem dúvida o direito fundamental a um processo tempestivo (art. $5^{\circ}$, LXXVIII, CF), não só o legislador é devedor de estruturas que possibilitem a adjudicação aos cidadãos de uma jurisdição com esses predicados, mas também o próprio Poder Judiciário coloca-se em uma situação de passividade em face dos cidadãos, porquanto os direitos fundamentais têm, entre nós, aplicação imediata (art. $5^{\circ}, \S 1^{\circ}, C F$ ). A doutrina, tanto constitucional (acerca, na doutrina brasileira, Ingo Wolfgang Sarlet, A Eficácia dos Direitos Fundamentais, 4. ed.. Porto Alegre: Livraria do Advogado, 2004, p. 225 e seguintes; na doutrina portuguesa, José Carlos Vieira de Andrade, Os Direitos Fundamentais na Constituição Portuguesa de 1976, 2. ed.. Coimbra: Almedina, 2001, p. 199 e seguintes), como a processual civil (assim, amplamente, Carlos Alberto Alvaro de Oliveira, "O Processo Civil na Perspectiva dos Direitos Fundamentais". In: Alvaro de Oliveira, Carlos Alberto (org.), Processo e Constituição. Rio de Janeiro: Forense, 2004, pp. 5/6; Luiz Guilherme Marinoni, Técnica Processual e Tutela dos Direitos. São Paulo: Revista dos Tribunais, 2004, pp. 165/247), é absolutamente tranqüila a respeito do ponto. No caso vertente, a postergação da decisão importou em verdadeira denegação da jurisdição de urgência, o que pode, induvidosamente, ser levado a este Tribunal de Justiça, à força dos preceitos constitucionais que regem a espécie. Pensar de modo diverso importa em ler o processo civil através de outro prisma 
que não o constitucional, o que é absolutamente inadmissível em face da força normativa da Constituição, que sói reconhecer-se no constitucionalismo contemporâneo (por todos, Konrad Hesse, A Força Normativa da Constituição. Porto Alegre: Sérgio Antônio Fabris Editor, 1991)".

Em breve apanhado, tal se oferece o modelo mínimo de direito processual civil no marco teórico do formalismo-valorativo.

\section{Conclusões}

As possíveis relações entre o direito constitucional e o direito processual civil foram alinhadas principalmente em duas vertentes: processualização da Constituição e constitucionalização do processo, chamandomse a atenção principalmente para o caráter heraclitiano e parmenidiano da Constituição e para a circunstância de ser hoje o direito processual civil nada além (e, fundamentalmente, nada aquém) do que direito constitucional aplicado. Logo em seguida, procurou-se demonstrar a essência constitucional do processo civil no marco teórico do formalismovvalorativo, fazendo-o à base da idéia de devido processo legal processual, desenho mínimo de nosso formalismo processual.

\section{Referências Bibliográficas}

ALEXY, Robert. Teoría de los Derechos Fundamentales. Madrid: Centro de Estudios Políticos y Constitucionales, 2001.

ALVARO DE OLIVEIRA, Carlos Aiberto. Do Formalismo no Processo Civil, 2. ed.. São Paulo: Saraiva, 2003.

. "A Garantia do Contraditório". In: Do Formalismo no Processo Civit, 2. ed.. São Paulo: Saraiva, 2003.

. "O Problema da Eficácia da Sentença". In: Revista Gênesis de Direito Processual Civil. Curitiba: Gênesis, 2003, n. 29.

. "O Processo Civil na Perspectiva dos Direitos Fundamentais". In: ALVARO DE OLIVEIRA, Carlos Alberto (org.), Processo e Constituição. Rio de Janeiro: Forense, 2004.

ALVARO DE OLIVEIRA, Carlos Alberto; LACERDA, Galeno. Comentários ao Código de Processo Civil, 6. ed.. Rio de Janeiro: Forense, 2002, vol. Vlli, tomo II.

ALVES, Francisco Glauber Pessoa. O Princípio Jurídico da Igualdade e o Processo Civil Brasileiro. Rio de laneiro: Forense, 2003.

ALVES, Maristela da Silva. "Processo e Constituição". In: Revista da Ajuris. Porto Alegre: s/ed., 2002, n. 85, tomol.

. "Princípio da Isonomia Constitucional". In: ALVARO DE OLIVEIRA, Carlos Alberto (org.), Processo e Constituição. Rio de laneiro: Forense, 2004.

ANDRADE, José Carlos Vieira de. Os Direitos Fundamentais na Constituição Portuguesa de 1976, 2. ed.. Coimbra: Almedina, 2001. 
ASSIS, Araken de. "Benefício da Gratuidade". In: Revista da Ajuris. Porto Alegre: s/ed., 1998, n. 73.

BAPTISTA DA SILVA, Ovídio Araújo. Curso de Processo Civil, 5. ed.. São Paulo: Revista dos Tribunais, 2000, vol. I.

. Curso de Processo Civil, 3. ed.. São Paulo: Revista dos Tribunais, 2000, vol. III.

"A 'Plenitude de Defesa' no Processo Civil". In: Da Sentença Liminar à Nulidade da Sentença. Rio de laneiro: Forense, 2001.

. "Direito Material e Processo". In: Gênesis Revista de Direito Processual Civil. Curitiba: Gênesis, 2004, n. 33.

- Processo e Ideologia - O Paradigma Racionalista. Rio de Janeiro: Forense, 2004.

BARBOSA MOREIRA, José Carlos. "A Motivação das Decisões como Garantia Inerente ao Estado de Direito". In: Temas de Direito Processual, $2^{\text {a }}$ ed.. São Paulo: Saraiva, 1988, Segunda Série.

"Publicité et Secret du Delibere dans la Justice Brésilienne". In: Temas de Direito Processual. São Paulo: Saraiva, 1989, Quarta Série.

"O Direito à Assistência Jurídica. Evolução no Ordenamento Brasileiro de Nosso Tempo". In: Revista da Ajuris. Porto Ảlegre: s/ed., 1992, n. 55.

. "A Justiça no Limiar de Novo Século". In: Revista Forense. Rio de Janeiro: Forense, 1992, n. 319.

"A Duração dos Processos: Alguns Dados Comparativos". In: Revista da Ajuris. Porto Alegre: s/ed., 2005, n. 98.

BARRETO, Ricardo de Oliveira Paes. Curso de Direito Processual Civil, 2. ed.. Rio de laneiro: Renovar, 2003.

BEDAQUE, José Roberto dos Santos. Direito e Processo - Influência do Direito Material sobre o Processo. Säo Paulo: Malheiros, 1995.

BONAVIDES, Paulo. Curso de Direito Constitucional, 7 ed., 2. tiragem. São Paulo: Malheiros, 1998.

BOURSIER, Marie-Emma. Le Principe de Loyauté en Droit Processuel. Paris: Dalloz, 2003.

BRITTO, Carlos Ayres. Teoria da Constituição. Rio de Janeiro: Forense, 2003.

CAMEJO FILHO, Walter. "Garantia do Acesso à Justiça". In: ALVARO DE OLIVEIRA, Carlos Alberto (org.), Processo e Constituiçăo. Rio de Janeiro: Forense, 2004.

CANARIS, Claus-Wilhelm. Pensamento Sistemático e Conceito de Sistema na Ciência do Direito, 3. ed.. Lisboa: Fundação Calouste Gulbenkian, 2002.

CANOTILHO, José Joaquim Gomes. "Tópicos de um Curso de Mestrado sobre Direitos Fundamentais, Procedimento, Processo e Organização". In: Boletim da Faculdade de Direito de Coimbra. Coimbra, 1990.

- Direito Constitucional e Teoria da Constimição, 3. ed.. Coimbra: Almedina, 1999.

CAPOGRASSI, Giuseppe. "Giudizio, Processo, Scienza, Verita". In: Rivista di Diritto Processuale. Padova: Cedam, 1950, vol, V, partel.

CAPPELLETTI, Mauro. "Spunti in Tema di Contraddittorio". In: Studi in Memoria di Salvatore Satta. Padova: Cedam, 1982, vol. I. - Juizes Irresponsáveis? Porto Alegre: Sérgío Antônio Fabris Editor, 1989. . Juízes Legisladores? Porto Alegre: Sérgio Antônio Fabris Editor, 1999.

CAPPELLETTI, Mauro; GARTH, Bryan. Acesso à Justiça. Porto Alegre: Sérgio Antônio Fabris Editor, 1988. 
CARNEIRO, Athos Gusmão. "Sentença Malfundamentada e Sentença NãoFundamentada. Conceitos. Nulidades". In: Revista da Ajuris. Porto Alegre: s/ed., 1995, n. 65.

CASTANHEIRA NEVES, Antônio. Metodologia Jurídica - Problemas Fundamentais. Coimbra: Coimbra Editora, 1993.

CASTRO, Fábio Caprio Leite de. "O Princfpio da Motivaçao enquanto Instrumento e Garantia no Sistema Jurídico Brasileiro". In: Revista da Ajuris. Porto Alegre: s/ed., 2003 , n. 90.

CHIARLONI, Sergio. "Questioni Rilevabili d'Ufficio, Diritto di Difesa e 'Formalismo delle Garanzie" ${ }^{\prime \prime}$. In: Rivista Trimestrale di Diritto e Procedura Civile. Milano: Giuffrè, 1987, parte II.

. "Il Nuovo art. 111 Cost. e il Processo Civile". In: Rivista di Diritto Processuale. Padova: Cedam, 2000, n. 4.

COMOGLIO, Luigi Paolo. La Garanzia Costituzionale dell'Azione ed il Processo Civile. Padova: Cedam, 1970.

"Modelli di Garanzia Costituzionale del Processo". In: Rivista Trimestrale di Diritto e Procedura Civile. Milano: Giuffrè, 1991.

CORDEIRO, Antônio Menezes. Introdução à Edição Portuguesa de Pensamento Sistemático e Conceito de Sistema na Ciência do Direito, de Claus-Wilhelm Canaris, 3. ed. Lisboa: Calouste Gulbenkian, 2002.

COUTURE, Eduardo Juan. "Las Garantías Constitucionales del Proceso Civil". In: Estudios de Derecho Procesal Civil. Buenos Aires: Ediar Editores, 1948, tomo I.

CRETELLA NETO, José. Fundamentos Principiológicos do Processo Civil. Rio de Janeiro: Forense, 2002.

CRUZ E TUCCl, José Rogério; TUCCl, Rogério Lauria. Constituição de 1988 e Processo - Regramentos e Garantias Constitucionais do Processo. São Paulo: Saraiva, 1989.

DANTAS, F. C. Santiago. "Igualdade perante a Lei e "Due Process of Law". In: Problemas de Direito Positivo. Rio de Janeiro: Forense, 1953.

DIDONE, Antonio. "Apuntes sobre la Duración Razonable del Proceso Civil". In: Revista Peruana de Derecho Procesal. Lima: Estudio Monroy Abogados, 2004, n. VII.

DINAMARCO, Cândido Rangel. Fundamentos do Processo Civil Modemo, 4. ed.. São Paulo: Malheiros, 2001, tomo I.

. Instituições de Direito Processual Civil, 3, ed.. Săo Paulo: Malheiros, 2003, vol.

FAZZALARI, Elio. "Procedimento (Teoria Generale)". In: Enciclopedia del Diritto. Milano: Giuffrè, 1986, vol. XXXV.

. "La Dottrina Processualistica Italiana: Dall"Azione' al 'Processo' (1864-1994)". In: Rivista di Diritto Processuale. Padova: Cedam, 1994, vol. XLIX, parte Il.

- Istituzioni di Diritto Processuale, 8. ed.. Padova: Cedam, 1996.

FERREIRA, Cristiane Catarina de Oliveira. "Visão Atual do Princípio do Juiz Natural". In: ALVARO DE OLIVEIRA, Carlos Alberto (org.), Processo e Constituição. Rio de Janeiro: Forense, 2004.

FLACH, Daisson. "Processo e Realização Constitucional: a Construção do 'Devido Processo'". In: AMARAL, Guilherme Rizzo e CARPENA, Márcio Louzada (coords.), Visões Críticas do Processo Civil Brasileiro - Uma Homenagem ao Prof. Dr. José Maria Rosa Tesheiner. Porto Alegre: Livraria do Advogado, 2005.

FLORES, Patrícia Teixeira Rezende; PÉCORA, Andréa. "Princípio da Publicidade: Restrições". In: Sérgio Gilberto Porto (org.), As Garantais do Cidadão no Processo Civil - Relações entre Constituição e Processo. Porto Alegre: Livraria do Advogado, 2003. 
GÁlVEZ, Juan Monroy. Introducción al Proceso Civil. Bogotá: Temis, 1996, tomo I.

GARTH, Bryan; CAPPELLETTI, Mauro. Acesso à justiça. Porto Alegre: Sérgio Antônio Fabris Editor, 1988.

GERAIGE NETO, Zaiden. O Princípio da Inafastabilidade do Controle Jurisdicional ... Art. 50, XXXV, da Constituição Federal. São Paulo: Revista dos Tribunais, 2003.

GILISSEN, John. Introdução Histórica ao Direito, 4. ed.. Lisboa: Fundação Calouste Gulbenkian, 2003.

GIULIANI, Alessandro. "L'Ordo Judiciarius Medioevale (Riflessioni su un Modello Puro di Ordine Isonomico)". In: Rivista di Diritto Processuale. Padova: Cedam, 1988, vol. XIIII, parte II.

GOMES DA SILVA, Nuno J. Espinosa. História do Direito Português. Lisboa: Fundação Calouste Gulbenkian, 1985, vol. I.

GRASSO, Eduardo. "La Collaborazione nel Processo Civile". In: Rivista di Diritto Processuale. Padova: Cedam, 1966, vol. XXI.

GRECO, Leonardo. "O Princípio do Contraditório". In: Revista Dialética de Direito Processual. São Paulo: Dialética, 2005, n. 24.

GRINOVER, Ada Pellegrini. As Garantias Constitucionais do Direito de Ação. São Paulo: Revista dos Tribunais, 1973.

- Os Princípios Constitucionais e o Código de Processo Civil. São Paulo: José Bushatsky Editor, 1975.

GUEDES, Jefferson Carús. O Princípio da Oralidade - Procedimento por Audiências no Direito Processual Civil Brasileiro. Săo Paulo: Revista dos Tribunais, 2003.

GUERRA FILHO, Wills Santiago. Teoria Processual da Constituição, 2. ed.. São Paulo: Celso Bastos Editor, 2000.

HESPANHA, Antônio Manuel Botelho. "Justiça e Administração entre o Antigo Regime e a Revoluçäo". In: HESPANHA, Antônio Manuel Botelho (org.) Justiça e Litigiosidade: História e Prospectiva. Lisboa: Fundaçäo Calouste Gulbenkian, 1992.

HESSE, Konrad. A Força Normativa da Constituição. Porto Alegre: Sérgio Antônio Fabris Editor, 1991.

KAFKA, Franz. O Processo, 6. reimpressão. São Paulo: Companhia das Letras, 2003.

KASER, Max. Direito Privado Romano. Lisboa: Fundação Calouste Gulbenkian, 1999.

LACERDA, Galeno; ALVARO DE OLIVEIRA, Carlos Alberto. Comentários ao Código de Processo Civil, 6. ed.. Rio de Janeiro: Forense, 2002, vol. VIll, tomo II.

LEAL, Rosemiro Pereira. Teoria Geral do Processo, 5. ed.. Säo Paulo: Thompson-IOB, 2004.

LIEBMAN, Enrico Tullio. "Diritto Costituzionale e Processo Civile". In: Problemi del Processo Civile. Napoli: Morano Editore, 1962.

. Manual de Direito Processual Civil. Rio de Janeiro: Forense, 1984, vol. I.

LOPES, João Batista. Curso de Direito Processual Civill. São Paulo: Atlas, 2005, vol. 1.

LUSSO, Francesco Paolo. Diritto Processuale Civile, 3. ed.. Milano: Giuffrè, 2000, vol. 1.

MACHADO, António Montalvão; PIMENTA, Paulo. O Novo Processo Civil, 4. ed.. Coimbra: Almedina, 2002.

MARINONI, Luiz Guilherme. Novas Linhas do Processo Civil, 4. ed.. São Paulo: Malheiros, 2000.

"O Direito à Efetividade da Tutela Jurisdicional na Perspectiva da Teoria dos Direitos Fundamentais". In: Gênesis Revista de Direito Processual Civil. Curitiba: Gênesis, 2003, n. 28. 
. Técnica Processual e Tutela dos Direitos. São Paulo: Revista dos Tribunais, 2004. . A Antecipação da Tutela, 8. ed.. São Paulo: Malheiros, 2004.

MATTOS, Sérgio Luiz Wetzel de. "O Processo Justo na Constituiçäo Federal de 1988". In: Revista da Ajuris. Porto Alegre: s/ed., 2003, n. 91.

MELO, Gustavo de Medeiros. "A Tutela Adequada na Reforma Constitucional de 2004". In: Revista de Processo. São Paulo: Revista dos Tribunais, 2005, n. 124.

MELLO, Cláudio Ari. Democracia Constitucional e Direitos Fundamentais. Porto Alegre: Livraria do Advogado, 2004.

MERRYMAN, John Henry. La Tradición Jurídica Romano-Canónica, 5. reimpressão. México: Fondo de Cultura Económica, 2000.

MILLAR, Robert Wyness. Los Principios Formativos del Procedimiento Civil. Buenos Aires: Ediar, 1945.

MIRANDA, Jorge. Manual de Direito Constitucional, 3. ed.. Coimbra: Coimbra Editora, 2000, tomo IV.

MITIDIERO, Daniel Francisco. Comentários ao Código de Processo Civil. São Paulo: Memória Jurídica Editora, 2004, tomo I.

"Processo e Cultura: Praxismo, Processualismo e Formalismo em Direito Processual Civil". In: Cadernos do Programa de Pós-Graduação em Direito PPGDir./UFRGS. Porto Alegre: PPGDir./UFRGS, 2004, n. II.

. "Processo e Cultura: Praxismo, Processualismo e Formalismo em Direito Processual Civil". In: Gênesis Revista de Direito Processual Civil. Curitiba: Gênesis, 2004, n. 33.

- "O Problema da Invalidade dos Atos Processuais no Direito Processual Civil Brasileiro Contemporâneo". In: AMARAL, Guilherme Rizzo e CARPENA, Márcio Louzada (coords.), Visöes Críticas do Processo Civil Brasileiro - Uma Homenagem ao Prof. Dr. José Maria Rosa Tesheiner. Porto Alegre: Livraria do Advogado, 2005.

. Comentários ao Código de Processo Civil. São Paulo: Memória Jurídica Editora, 2005, tomo II.

. Elementos para uma Teoria Contemporânea do Processo Civil Brasileiro. Porto Alegre: Livraria do Advogado, 2005.

MITIDIERO, Daniel Francisco; ZANETI JÚNIOR, Hermes. Introdução ao Estudo do Processo Civil - Primeiras Linhas de um Paradigma Emergente. Porto Alegre: Sérgio Antônio Fabris Editor, 2004.

MONIZ DE ARAGÃo, Egas Dirceu. Comentários ao Código de Processo Civil, 9. ed.. Rio de Janeiro: Forense, 1998, vol. 11.

MONTESANO, Luigi. "La Garanzia Costituzionale del Contraddittorio e i Giudizi di 'Terza Via'". In: Rivista di Diritto Processuale. Padova: Cedam, 2000.

MORELLO, Augusto M.. Constitución y Proceso - La Nueva Edad de las Garantías Jurisdiccionales. La Plata: Libreria Editora Platense, 1998.

NERY JÚNIOR, Nélson. Princípios do Processo Civil na Constituição Federal, 5. ed.. São Paulo: Revista dos Tribunais, 1999.

ORESTANO, Riccardo. "Azione. I - L'Azione in Generale: a) Storia del Problema". In: Enciclopedia del Diritto. Milano: Giuffrè, 1959, vol. IV.

PALACIOS, Juan José Monroy. Bases para la Formulación de una Teoría Cautelar. Lima: Comunidad, 2002.

PÉCORA, Andréa; FLORES, Patrícia Teixeira Rezende. "Princípio da Publicidade: Restrições". Ín: Sérgio Gilberto Porto (org.), As Garantais do Cidadão no Processo Civil - Relaçōes entre Constituição e Processo. Porto Alegre: Livraria do Advogado, 2003. 
PÉREZ, Alex Carocca. "Garantía Constitucional de la Defensa". In: Revista Peruana de Derecho Procesal. Lima: Estudio Monroy Abogados, 1998, vol. Il.

PICARDI, Nicola. "Il Principio del Contraddittorio". In: Rivista di Diritto Processuale. Padova: Cedam, 1998, parte 11.

. "Audiatur et Altera Pars': Le Matrici Storico-Culturali del Contraddittorio". In: Rivista Trimestrale di Diritto e Procedura Civile. Milano: Giuffè, 2003, n.1.

"La Vocazione del Nostro Tempo per la Giurisdizione". In: Rivista Trimestrale di Diritto e Procedura Civile. Milano: Giuffrè, 2004, n. 1.

PICÓ I JUNOY, Joan. "El Sistema Español de Garantías Constitucionales del Proceso". In: Revista Peruana de Derecho Procesal. Lima: Estudio Monroy Abogados, 1999, vol. Ill.

PIMENTA, Paulo; MACHADO, António Montalvăo. O Novo Processo Civil, 4. ed.. Coimbra: Almedina, 2002.

PONTES DE MIRANDA, Francisco Cavalcanti. Os Fundamentos Actuaes do Direito Constitucional. Rio de Janeiro: Freitas Bastos, 1932.

. Comentários à Constituição de 1967 com a Emenda n. 1, de 1969, 2. ed.. São Paulo: Revista dos Tribunais, 1971, tomo V.

. Comentários ao Código de Processo Civil, 5. ed.. Rio de Janeiro: Forense, 1997, tomol.

. Comentários ao Código de Processo Civil, 4. ed.. Rio de Janeiro: Forense, 1997, tomo Ill.

PORTANOVA, Rui. Princípios do Processo Civil, 2. tiragem. Porto Alegre: Livraria do Advogado, 1997.

PROTO PISANI, Andrea. "Dell'esercizio dell'azione". In: ALLORIO, Enrico (coord.), Commentario del Codice di Procedura Civile. Torino: UTET, 1973, vol. I, tomoll. . Lezioni di Diritto Processuale Civile, 4. ed.. Napoli: Jovene, 2002.

. "Giusto Processo e Valore della Cognizione Piena". In: Rivista di Diritto Civile. Padova: Cedam, 2002, n. 2.

ROFFO, Juan Carlos Bavasso. Publicidad del Proceso. Buenos Aires: Abeledo-Perrot, 1961.

SAMPAIO, José S.. Os Prazos no Código de Processo Civil, 6. ed.. São Paulo: Revista dos Tribunais, 2002.

SANTOS, Boaventura de Sousa. Pela Mão de Alice - O Social e o Político na PósModernidade, 9, ed.. São Paulo: Cortez Editora, 2003.

SANTOS, Moacyr Amaral. Primeiras Linhas de Direito Processual Civil, $10^{\text {a }}$ ed.. São Paulo: Saraiva, 1983, vol. 1.

SARLET, Ingo Wolfgang. A Eficácia dos Direitos Fundamentais, 4. ed.. Porto Alegre: Livraria do Advogado, 2004.

SILVA, Carlos Augusto. "O Princípio do Juiz Natural e sua Repercussão na Jurisprudência do Supremo Tribunal Federal". In: ALVARO DE OLIVEIRA, Carlos Alberto (org.), Processo e Constituição. Rio de Janeiro: Forense, 2004.

SILVA, Eduardo Silva da. Arbitragem e Direito da Empresa - Dogmática e Implementação da Cláusula Compromissória. São Paulo: Revista dos Tribunais, 2003.

. "Constituição, Jurisdição e Arbitragem". In: ALVARO DE OLIVEIRA, Carlos Alberto (org.), Processo e Constituição. Rio de laneiro: Forense, 2004.

SILVA, José Afonso da. Curso de Direito Constitucional Positivo, 14. ed.. São Paulo: Malheiros, 1997.

SILVA, José Milton. Teoria Geral do Processo, 2. ed.. Rio de Janeiro: Forense, 2003. 
SILVA ALBERTON, Cláudia Marlise da. Publicidade dos Atos Processuais e Direito à Informação. Rio de Janeiro: Aide Editora, 2000.

TARUFFO, Michele. La Motivazione della Sentenza Civile. Padova: Cedam, 1975.

"Il Significato Costituzionale dell'Obbligo di Motivazione". in: DINAMARCO, Cândido Rangel; GRINOVER, Ada Pellegrini; WATANABE, Kazuo (coord.). Participação e Processo. São Paulo: Revista dos Tribunais, 1988.

TARZIA, Giuseppe. "Parità delle Armi tra le Parti e Poteri del Giudice nel Processo Civile". In: Problemi del Processo Civile di Cognizione. Padova: Cedam, 1989.

- Lineamenti del Processo Civile di Cognizione, 2. ed. Milano: Giuffrè, 2002.

TESHEINER, José Maria Rosa. Elementos para uma Teoria Geral do Processo. São Paulo: Saraiva, 1993.

TROCKER, Nicolò. Processo Civile e Costituzione - Problemi di Diritto Tedesco e Italiano. Milano: Giuffrè, 1974.

"Il Nuovo articolo 111 della Costituzione e il 'Giusto Processo' in Materia Civile: Proflili Generali". In: Rivista Trimestrale di Diritto e Procedura Civile. Milano: Giuffrè, 2001, n. 2.

TUCCl, Rogério Lauria; CRUZ E TUCCl, José Rogério. Constituição de 1988 e Processo - Regramentos e Garantias Constitucionais do Processo. Săo Paulo: Saraiva, 1989.

USTÁRROZ, Daniel. "A Democracia Processual e a Motivação das Decisões judiciais". In: Porto, Sérgio Gilberto (org.), As Garantias do Cidadão no Processo Civil Relações entre Constituição e Processo. Porto Alegre: Livraria do Advogado, 2003.

VERDE, Giovanni. "Giustizia e Garanzie nella Giurisdizione Civile". In: Rivista di Diritto Processuale. Padova: Cedam, 2000, n. 2.

VERDÚ, Pablo Lucas. Sentimento Constitucional - Aproximação ao Estudo do Sentir Constitucional como Modo de Integraçăo Poĺtica. Rio de Janeiro: Forense, 2004.

VESCOVI, Enrique. "Hacia un Proceso Civil Universal". In: Revista de Processo. São Paulo: Revista dos Tribunais, 1999, n. 93.

VIGNERA, Giuseppe. "Le Garanzie Costituzionali del Processo Civile alla Luce del 'Nuovo' art. 111 Cost.". In: Rivista Trimestrale di Diritto e Procedura Civile. Milano: Giuffrè, 2003, n. 4.

VILLEY, Michel. Filosofia do Direito. Săo Paulo: Martins Fontes, 2003.

YARSHELL, Flávio Luiz. Tutela Jurisdicional. São Paulo: Atlas, 1998.

ZANETI IÚNIOR, Hermes. "Direito Material e Direito Processual: Relaçoes e Perspectivas". In: Revista Processo e Constituição - Coleção Galeno Lacerda de Estudos de Direito Processual Constitucional. Ponto Alegre: Faculdade de Direito UFRGS, 2004, n. 1.

. "Processo Constitucional: Relações entre Processo e Constituição". In: Introdução ao Estudo do Processo Civil - Primeiras Linhas de um Paradigma Emergente. Porto Alegre: Sérgio Antônio Fabris Editor, 2004, em co-autoria com MITIDIERO, Daniel Francisco.

ZANETI JÚNIOR, Hermes; MITIDIERO, Daniel Francisco. Introdução ao Estudo do Processo Civil - Primeiras Linhas de um Paradigma Emergente. Porto Alegre: Sérgio Antônio Fabris Editor, 2004.

ZAVASCKI, Teori Albino. Antecipação da Tutela, 2. ed.. São Paulo: Saraiva, 1999. 